\title{
LA «METAFÍSICA» DEL JOVEN RAWLS: UNA TEOLOGÍA CON IMPLICACIONES ÉTICAS Y POLÍTICAS *
}

\author{
Emilio José Rojas Molina \\ Universidad de Salamanca
}

RESUMEN. Este trabajo se ocupa, con motivo de su reciente publicación, de la tesis de grado de J. RAWLS, un escrito de carácter teológico, no exento, sin embargo, de implicaciones éticas y políticas, y, por consiguiente, muy alejado, tanto en sus presupuestos como en sus propósitos, de la obra hasta ahora conocida del autor. Evidenciado lo anterior, introduce al lector en sus contenidos teológicos básicos, fundamentalmente los que tienen que ver con el pecado y la fe, pasando después a ocuparse de la relevancia que este primer ensayo puede tener, y como parte de esta cuestión, particularmente de la relación que cabe establecer entre este escrito de juventud y su obra madura. Para ello, y a modo de ejemplo, fija varios puntos de continuidad y de fricción entre ambos, descartando una relectura religiosa de su teoría de la justicia apoyada en aquel primer trabajo.

Palabras clave: RAWLS, religión, ética, comunidad.

ABSTRACT. This paper is concerned, on the occasion of its recent publication, with J. RAWLs's undergraduate senior thesis, a theological work with ethical and political implications, and, for this reason, very different in its foundations and purposes to the rest of his best known works. Once this is clear, it introduces the reader to its main theological ideas, basically those related to sin and faith. Then it focuses on the question of the relevancy of this early text, and as part of it, on the relation that could be established between this youthful writing and his mature work. In this respect, and as an example, it points out several continuities and discontinuities between them, rejecting a religious reinterpretation of his theory of justice on the basis of that first essay.

Keywords: RaWLS, religion, ethics, community.

* Fecha de recepción: 30 de marzo 2010. Fecha de aceptación: 20 de abril de 2010.

Me gustaría agradecer los valiosos comentarios y sugerencias que sobre el borrador de este trabajo me trasladaron los profesores Miguel Ángel Rodilla, J. Delgado Pinto, Lourdes Santos, J. M. Pérez Bermejo, J. M. ${ }^{a}$ Garrán y J. A. Ramos Pascua. También quisiera señalar que mi interés por confeccionar este artículo tiene su origen en una nota crítica que a propósito del hasta ahora último libro de RAWLS (2009), e incitado a ello por el profesor E. Bonete, escribí para la revista Teorema, vol. XXIX/1 (invierno de 2010). 


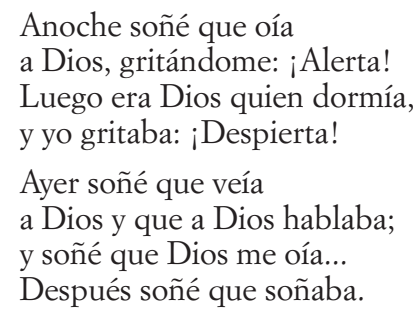

Antonio MACHADO, Proverbios y cantares

\section{DE ERIZOS QUE QUIZÁS SEPAN «MÁS DE UNA COSA»}

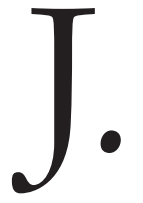

RAWLS es probablemente la figura más importante e influyente de la filosofía moral y política del siglo Xx. Sus trabajos, que se extienden a lo largo de más de cinco décadas, desde mediados del siglo pasado hasta nuestros días, han fijado buena parte de la agenda de la filosofía moral y política, no sólo anglosajona, sino, en general, de la mayoría de países que comparten la cultura política occidental, determinando en gran medida el debate contemporáneo que, en efecto, en el seno de la filosofía, pero también del Derecho, la ciencia política, la teoría económica y otra serie de disciplinas sociales, se ha producido en torno a la cuestión de la justicia social y política. Los escritos de RAWLS han contribuido decisivamente no sólo a configurar un planteamiento novedoso, y sin embargo conectado al pensamiento de los clásicos, sobre todo, de los modernos, de los problemas de justicia, sino también a un mejor entendimiento de aquéllos inherentes a las ideas de democracia y constitucionalismo, y más recientemente de las cuestiones relacionadas con la justicia entre naciones. Por tanto, no parece exagerado afirmar, como hiciera R. NozicK en su bien conocida sentencia, que «ahora los filósofos políticos tienen que trabajar dentro de la teoría de RAwLS, o bien, explicar por qué no lo hacen» (1974: 183).

Entre las razones que explican el impacto tan amplio que ha tenido su obra ( $c f r$. Rodilla, 2006, 19-60), me gustaría subrayar dos. Por un lado, el haber sido capaz de reestructurar a través de la reflexión y de la crítica un conjunto de ideas que, si bien de forma desorganizada, están presentes en el common sense de la sociedades democráticas, formando parte de un trasfondo de convicciones implícitas en la «cultura pública» de aquéllas (ibid., 20), si se quiere, su capacidad para dar «expresión filosófica» a nuestras convicciones morales y políticas más profundas. Por otro, pero no ajeno a lo anterior, una «resuelta intención práctica», que se enmarca dentro de los intentos más recientes de «rehabilitación de la filosofía práctica» (cfr. v. gr. APEL, 1973, o HABERMAS, 1983: 1991), y que tiene que ver con la pretensión de RAWLS de construir una teoría que pueda proporcionar principios capaces de suscitar un consenso público efectivo a propósito de los que son básicos para el orden jurídico y político, y servir de ese modo como criterio de justificación racional y como canon crítico del propio sistema social (RoDilla, 2006: 21 y ss.).

Nada tiene de extraño, pues, que la literatura sobre RAWLS sea inmensa, no ya para lo que sería más o menos normal con respecto a un filósofo de primer orden de nuestro 
tiempo, cuyo trabajo, no obstante, es relativamente reciente, sino, en general, incluso para lo que comparativamente puede esperarse en relación a cualquier pensador de talla universal de los habitualmente considerados como clásicos (KUKATHAS, 2003: 6; cfr. GRAHAM, 2007: 1). Pese a toda la enorme diversidad de comentarios y análisis que la obra de RAWLS ha suscitado, lo cierto es que desde el comienzo RAWLS dedica todos sus esfuerzos a una sola cuestión filosófica que ha dominado su pensamiento por completo, con sus paulatinos complementos y desarrollos, la de cuál es la concepción de la justicia más adecuada para la «estructura básica» de una sociedad democrática, un tema sobre el que escribió bastante más que cualquier otro filósofo de su tiempo (KukAthas, 2003: 1; FreEman, 2007: x; cfr. Freeman, 2003: 1). Si tomásemos como referencia aquella idea que, a partir de un fragmento del poeta griego ARQUíloco, desarrollara I. BERLIN en su ensayo de 1953, El erizo y la zorra (vid. 39-40), y según la cual existirían dos grupos entre los grandes escritores y pensadores, e incluso entre los hombres en general, el de las zorras, los que saben muchas cosas, y el de los erizos, los que conocen una importante ${ }^{1}$, RAWLS, sin duda, pertenecería al de estos últimos, pues la suya fue solamente una gran idea: la «justicia como equidad», sobre la que elaboró una construcción teórica tan imponente como la que conocemos.

Pues bien, parece que la nómina de quienes se han ocupado de comentar, discutir o criticar la obra de RAWLS, entre los que figuran muchos de los teóricos morales y políticos contemporáneos más importantes, como J. HABERMAS, R. RORTY, A. SEN, H. L. A. HART, R. DwORKIN o J. RAZ, por citar algunos, está condenada a seguir creciendo. Y no sólo por el permanente rastreo y escrutinio al que continúa siendo sometida, ejemplo de lo cual es el gran número de publicaciones que cada año se registran a propósito de su teoría, sino también, y por cuanto aquí interesa, porque aun transcurrido ya un cierto tiempo desde la muerte del autor a comienzos de la pasada década, siguen apareciendo libros con su nombre ${ }^{2}$.

Primero fueron sus Lectures on the History of Political Philosophy (2007), que recogen la lectura que RAWLS realiza de los filósofos políticos modernos más relevantes, de HobBes, de Locke, de Rousseau, o de contemporáneos como Mill, Sidgwick o MARX. Junto a sus anteriores Lectures on the History of Moral Philosophy (2000), en las que daba cuenta, entre otros, de HumE o KANT, esas lecciones, sin formar parte del cuerpo de la teoría de la justicia, arrojan una valiosa luz sobre su obra y suministran al intérprete o crítico una excelente herramienta para completar su análisis. No en vano, puede decirse que RAWLS trató de asumir críticamente e intentó reformular muchas de las ideas presentes en las obras de aquéllos, los filósofos morales y políticos más importantes desde Platón y ARISTÓTELES, y, seguramente por eso mismo, en cierta forma su

\footnotetext{
${ }^{1}$ Como el propio BeRLIN admite, los estudiosos discrepan acerca de «la correcta interpretación de tan oscuras palabras». Aunque yo las acojo en su exégesis berliniana, lo hago en su tenor más literal, prescindiendo, por tanto, de la lectura más concreta que el pensador angloletón hace de ellas.

2 Con esta expresión, «libros con su nombre», no pretendo poner en cuestión la autoría de RAWLS, fuera de toda duda, sino expresar lo siguiente: $a$ ) con respecto a la primera de las dos obras a las que me refiero inmediatamente (RAWLS, 2007), las resistencias que durante mucho tiempo RAWLS mostró hacia su publicación, a la que sólo accedió poco antes de su fallecimiento tras una larga enfermedad, y para la que además fue necesaria una cierta labor de edición en varias de las lecciones que la componen (vid. FREEMAN, 2007b, esp. xvs.); b) en relación a la segunda (RAWLS, 2009), la más que dudosa conformidad, como se admite en la introducción que dos de sus discípulos han confeccionado para la misma, que RAWLS hubiese dado a que esta obra viese la luz (vid. COHEN y NAGEL, 2009: 3 y ss.).
} 
filosofía puede interpretarse como un diálogo permanente con ellos (FrEEMAN, 2007, 13-14), en el que RAWLS trata de responder a muchas de las cuestiones que, de una u otra manera, estos pensadores, de HOBBES en adelante, plantearon o al menos apuntaron incipientemente (ibid., 28).

Ahora aparece un nuevo trabajo que, a diferencia de aquellas lecciones, dada la aparente dificultad de su encaje dentro del homogéneo y hasta ahora conocido programa de investigación rawlsiano, parecería más bien susceptible de suscitar ciertos debates o polémicas. Me refiero a A Brief Inquiry into de Meaning of Sin and Faith: An Interpretation Based on the Concept of Community (1942), tesis de grado de RAWLS, publicada por Harvard University Press más de sesenta años después de su defensa en 2009, y cuya edición ha corrido a cargo de Th. NAGEL ${ }^{3}$. Nos encontramos aquí con un escrito de juventud, que RAWLS elabora en un momento de su vida de profunda religiosidad, y en el que, como su propio título indica, pretende abordar una cuestión específicamente religiosa, aquella que tiene que ver con la interpretación del pecado y, por ende, de la fe, valiéndose de los conceptos de comunidad y personalidad, según él las «categorías adecuadas» para ello (108).

En la que, por consiguiente, puede considerarse primera obra de RAWLS, sus interlocutores principales, y en este caso objeto de abierta crítica, no son ROUSSEAU o KANT. Es cierto que como consecuencia de su propia cosmovisión, concretamente de las relaciones que establece entre personalidad y comunidad ( $v i d .112,121,126-127$ ), y del análisis que, conforme a aquélla, realiza sobre los orígenes y consecuencias del pecado, particularmente del egoísmo (vid. 183 y ss.), rechaza cualquier teoría contractualista de la sociedad, explícitamente las de HOBBES y LOCKE, cuyas ideas sobre la justicia suponen, según él, una concepción equivocada de la comunidad (vid. 126-127, 188-189, 227-229). Pero esencialmente lo que sus páginas recogen es una discusión con A. De Hipona o T. DE Aquino como deudos de Platón y Aristóteles, y de forma más general, con un modo de entender el universo, al que denomina «naturalismo» (107), que, con arreglo a su explicación, habría dominado el pensamiento occidental, y que él identifica con la reducción de todas las relaciones que en el mundo existirían a las meramente «naturales», las que se producen entre una persona y un objeto (114), y, así, con la degradación de la «vida espiritual» a algo propio del ámbito de los deseos o apetitos (107). Esta concepción, cuyos orígenes sitúa, por tanto, en el mundo griego, es la que, a juicio de RAWLS de forma equivocada, el cristianismo habría asumido tradicionalmente y, en este sentido, la que se refleja en las obras de autores tan relevantes para la cristiandad como los ya mencionados (ibid., 115), impidiéndole, desde una confusión de «lo natural» y «lo personal» (vid. 112, 118), entender no sólo la «verdadera naturaleza» de Dios (120), y con ella la del mismo cosmos (vid. 107, cfr. 126), sino también lo que significa la propia fe, y como «antítesis» de ella el pecado (vid. 214, 243).

Como puede adivinarse, para el análisis que esta temprana investigación supone, sus referencias o fuentes principales, a partir de las cuales persigue, frente a aquellas «teologías naturalistas» (119), construir una teología basada en una concepción del universo esencialmente «personal» (vid. 112 y ss.), tampoco son Du Contrat Social,

3 Salvo que se considere necesario para evitar equívocos, en adelante todas las citas al trabajo de grado de RAWLS se hacen únicamente remitiendo a las páginas de esta edición, y omitiendo la fecha de publicación. 
cuya idea de «voluntad general», sin embargo y aun sin citar a ROUSSEAU, sí rechaza expresamente (127), o la Grundlegung kantiana, sino la Biblia, los escritos de MARTín LUTERO o los trabajos de teólogos neortodoxos como E. BRUNNER o A. NYGREN. Porque para el joven RAWLS el universo supone una comunidad de personas relacionadas con Dios, quien, no sólo habría creado el mundo, sino que lo habría hecho para la constitución de dicha comunidad, fin al que se dirigiría la propia creación $(108,112)$. Es más, la capacidad del hombre para formar parte de la comunidad y participar de ella, que es lo que define su naturaleza ( vid. 112, 121, 215), refleja su semejanza con Dios, es consecuencia directa de ella, pues éste, siendo trino, argumenta el joven filósofo, es él mismo comunidad $(113,121,193)$.

Pese a todo, y aun cuando tratándose de un trabajo de carácter fundamentalmente teológico es evidente que queda fuera del arco temático de su teoría de la justicia, en modo alguno puede considerarse completamente ajeno a cuestiones que sí tienen que ver con su filosofía moral y política, particularmente dadas las consecuencias e implicaciones que con respecto a aquéllas el joven RAWLS atribuye a la visión que en él se expone (110), y que podrían cifrarse en la imposibilidad de disociar religión, ética y política $(114,127-128)$. Esto quizás genere nuevos debates en torno al pensamiento de RAWLS, pero, a mi juicio, básicamente invita a realizar un estudio sobre las relaciones que a propósito de esta cuestión pueden establecerse entre ambos extremos de su pensamiento, y como posteriormente explicaré con más detalle, sobre todo refuerza la idea de fricción entre su escrito de juventud y su obra madura en este punto. Sin embargo, dentro todavía de los posibles interrogantes, y aun en otro orden de cosas, algunas preguntas parecen obligadas: ¿Es que acaso hubo un tiempo en que el erizo sabía, en efecto, de otras cosas? ¿O es que sólo empezó a serlo, y, sin embargo, quizás precisamente por eso mismo, tras caerse del caballo ${ }^{4}$. ¿Traen sus púas causa, por tanto, de un desencuentro con Dios? Con respecto a esto último, así parecerían haberlo entendido quienes interpretan que el interés de RAWLS por la justicia, particularmente por la posibilidad real de una sociedad justa, nace de una preocupación previa por la cuestión, sin embargo, esencialmente religiosa, de la existencia del mal en el mundo, por sus causas y por lo que significa, tanto individual como colectivamente, para la vida de los hombres (vid. FreEman, 2007: 5, 11; cfr. POGGE, 2007: 26 y ss.). Por mi parte, sólo responderé aquí de manera breve. Ese «más de una cosa» con el que abría este epígrafe pudiera, no lo niego, aludir a algo que hiciera del erizo, siquiera sólo por esta vez, zorra, algunos estarán tentados de interpretarlo así, o más bien, como creo yo e intentaré poner de manifiesto a lo largo de estas páginas, podría sintetizar el que el conocimiento que el erizo tenía sobre esa misma cosa era aún más amplio, y quizás también más personal, de lo ya sabido, lo que en todo caso, como también trataré de exponer más detalladamente, no alteraría en modo alguno la naturaleza de su obra.

\section{2. ¿UN RAWLS ABIERTAMENTE RELIGIOSO?}

A diferencia de lo que ocurre con otros autores, por ejemplo, con filósofos como NiETZSCHE, en los que el conocimiento de los sucesos y aconteceres que conformaron

${ }^{4}$ Vid. infra 2.3. Al contrario que Pablo de Tarso. 
su existencia pueden resultar de utilidad y arrojar cierta luz sobre el carácter de su obra, o sencillamente ser imprescindibles, como, en efecto, sucede en el caso del autor de El Anticristo, lo cierto es que para entender el trabajo de RAWLS, para comprender su teoría de la justicia como una expresión del liberalismo político, su biografía no es esencial. Su obra se explica por sí misma, y no sólo por lo explícito de sus propósitos, ejemplo de lo cual son los prefacios de sus libros, a los que siempre concedió RAWLS gran importancia, sino también por el elevado grado de sistematicidad desplegado en la exposición de sus argumentos en los que los presupuestos que sirven de base a sus conclusiones aparecen perfecta y meticulosamente detallados. Eso no es óbice para asumir que muchas de las experiencias vividas por RAWLS a lo largo de su vida influyeron en el desarrollo de su pensamiento.

Conforme a lo anterior, un conocimiento más personal sobre el autor no dejaría de ser algo, en efecto, completamente accesorio con respecto a la obra hasta ahora conocida por el gran público si no fuese por la sorpresa e incluso contrariedad que puede producir en muchos el hecho de que ahora se ponga a disposición de todos a través de su publicación un trabajo de carácter fundamentalmente teológico, y que recoge en gran medida las creencias religiosas del propio autor, tratándose éste de un filósofo como RAWLS. Esa extrañeza sería bien explicable. Es verdad que a través de sus escritos, y a diferencia de otros teóricos en la órbita del liberalismo, RAWLS ha mostrado una enorme sensibilidad hacia el fenómeno religioso en general y hacia las creencias religiosas de las personas en particular, a las que ha incorporado normativamente a la arquitectura de su obra como parte de las premisas y presupuestos que condicionan su propia construcción ${ }^{5}$. Pero no puede ignorarse que, pese a ello, también ha excluido explícitamente la posibilidad de que la religión, y en este sentido, alguna doctrina religiosa, pueda proporcionar una base común y factible para articular, como «base de justificación pública», la concepción política de la justicia de una sociedad democrática. Como él mismo ha explicado, en vista de las «profundas diferencias» que la diversidad de doctrinas característica de tales sociedades genera, no parece razonable esperar que alguna de estas doctrinas pueda suscitar un consenso político fundamental entre personas que sustentan visiones del mundo cuando menos diferentes. En todo caso, esto no implica la negación de aquéllas, sino, más bien, el reconocimiento de su trascendencia y la delimitación de las posibilidades prácticas de nuestro mundo social, que imponen la búsqueda de consensos éticos y políticos que permitan a las personas una coexistencia pacífica, para todos provechosa y sobre todo justa ( $c f r$. 1985: 395, 388; 1987: 425, 434-435; 1989: 474-475 y 478).

De modo que del problema, por lo que aquí interesa y para simplificar, de la relación entre religión y democracia y, así, de las condiciones de compatibilidad entre am-

5 Para ilustrar ese papel de la religión en la teoría de la justicia de RAWLS pondré dos sencillos ejemplos: i) entre los argumentos que dentro de ella se esgrimen en favor de la prioridad de las libertades básicas, y, en consecuencia, de los principios de justicia que RAWLS propone, la posibilidad de que las convicciones que las personas tienen sean religiosas resulta decisiva (vid. v. gr. 1982: 24 y ss., donde se discuten las razones para conceder esa precedencia a la libertad de conciencia; $c f r$. 1971, 205 y ss.); ii) en la formulación de una concepción política de la justicia, como inmediatamente se advierte arriba en el texto, RAWLS asume que el primer rasgo de la cultura política de una sociedad democrática que ha de ser tenido en cuenta es la diversidad de doctrinas que forman parte de la misma, entre las cuales las religiosas son referencia obligada ( $c f r$. 1987: 425; 1989: 474 y ss.). 
bas a propósito del papel que una concepción de la justicia debe desempeñar en una sociedad democrática, cuestión que está en el origen del liberalismo político tal y como RAWLS lo entiende ( $c f r$. 1996, xxxix; vid. 1998, 617), con la aparición en escena del trabajo de grado de RAWLS la audiencia se ve retrotraída súbitamente a un escenario bien diferente. En él la cuestión que se pretende abordar es una cuestión inequívocamente religiosa, aquella que tiene ver con la interpretación del pecado y de la fe, que se examina sobre las bases de un cristianismo de corte protestante, pero que, sin embargo, en último término, y pese a esa inmediata especificidad de su objeto, conduce a una interpretación completamente teológica de la propia teoría ética.

Por todo ello me parece justificado enmarcar la exposición de los contenidos de A Brief Inquiry into the Meaning of Sin and Faith dentro de un relato, siquiera sea breve, de la relación del joven RAWLS con la religión que permita entender mejor las razones que llevan a un estudiante de filosofía cuyo vínculo con aquélla no puede describirse como particularmente estrecho a adquirir un profundo interés por la teología, así como cuáles fueron las que le llevaron a abandonar sus creencias, un recorrido en cuyo tramo final se empiezan a sentar ya las bases del filósofo moral y político que conocemos. Recurro para ello a los trabajos de PogGe (2007: 3-27), FREEMAN (2007: 1-12), y GRAHAM (2007: 1-14), así como al propio RAWLS y su «On My Religion». Es este último un breve escrito elaborado por RAWLS a mediados de los noventa, e incluido en el volumen que aquí examinamos (259-269), que no parece que pretendiera ver publicado, en el que explica la historia de sus creencias religiosas, y en particular la de algunas de sus reflexiones sobre el fenómeno religioso, combinando pasajes claramente autobiográficos con otros de carácter más propiamente filosófico, de cuya unión resulta una descripción de su relación, tanto personal como intelectual, con la religión. Pequeña joya para los lectores de RAWLS, pese a la renuncia a cualquier interés que pudiera tener para otros con la que abre el texto (261), en lo filosófico resulta especialmente interesante con respecto a la problemática del liberalismo político $(264 \text { y ss. })^{6}$.

\subsection{Más allá de una religiosidad convencional}

RAWLS nace en el seno de una familia cristiana, de padre metodista y madre episcopaliana, y en su adolescencia permanece cuatro años, los correspondientes a la enseñanza secundaria, en un internado religioso al oeste de Connecticut, el Kent School. El Kent era un estricto centro sólo para chicos dirigido por un monje de la Orden de la Santa Cruz bastante severo y dogmático, y en el que los estudiantes debían asistir a los servicios religiosos a diario. Pese a ello RAWLS nunca tuvo la sensación de que ni sus padres ni él mismo fuesen personas especialmente religiosas más que en un sentido meramente convencional. De hecho, solía recordar la época del Kent School como un tiempo no demasiado feliz y poco provechoso, en el que los estímulos intelectuales eran más bien escasos.

\footnotetext{
${ }^{6}$ Aunque publicado ahora por primera vez junto a su tesis de grado, en una opción editorial que dado su contenido resulta particularmente oportuna, «On My Religion» no puede, sin embargo, considerarse un ensayo del todo desconocido, pues tanto Th. PoGge (2007: 13-14) como S. FrEEMAN (2007: 9-10) se refieren a él en sus trabajos, reproduciendo incluso algunos de sus pasajes.
} 
Pero después, en la universidad, con el tiempo, las cosas cambiarían. A su llegada a Princeton, RAWLS ni siquiera tenía demasiado claro qué estudios seguir, coqueteando con disciplinas tan dispares como la química, las matemáticas, la historia del arte o la música, y, en este sentido, puede decirse que terminaría estudiando filosofía casi por casualidad. En cambio, la segunda mitad de su etapa como estudiante universitario describe a un joven profundamente interesado por la teología que incluso llega a plantearse seriamente ingresar en el seminario para acceder al sacerdocio. RAWLS pospondrá esta decisión ante la realidad de un conflicto bélico, la Segunda Guerra Mundial, en el que, al igual que otros jóvenes venían haciendo, se sentía obligado a participar. Aunque también decide aguardar a que la contienda concluya porque no está completamente seguro de sus intenciones.

Como estudiante de filosofía RAWLS había asistido a las clases de W. T. STACE, quien posteriormente dirigiría su tesis doctoral, y D. BOwERs, las cuales habían girado básicamente en torno al utilitarismo y al kantismo respectivamente, doctrinas posteriormente de enorme importancia por diferentes, pero relacionados, motivos para su teoría de la justicia. Sin embargo, en aquel momento, sería otra figura, la de N. MALCOM, con quien más tarde y durante el disfrute de una beca predoctoral coincidiría en la Universidad de Cornell, la que, curiosamente, tras haber provocado en él, a través de su ejemplo y, particularmente, de su actitud crítica, una mayor atracción hacia la filosofía, despertaría sin proponérselo su interés por la teología. Curiosamente y, es más que probable, de manera inopinada, porque MALCOM era alguien que había trabajado con WitTGENSTEIN en Cambridge y cuyos intereses filosóficos no eran precisamente los religiosos ${ }^{7}$.

Sea como fuere, durante la primavera de 1942, y probablemente influido por la propia contienda, MALCOM impartió un curso sobre la cuestión, «cuasi-religiosa» la denominaría más tarde RAWLS ${ }^{8}$, de la maldad humana sirviéndose de textos de PLATÓN, de A. DE HipOnA, del teólogo norteamericano R. NiEbuHR, del filósofo británico Ph. LEON, estos dos figuras prominentes de la neortodoxia cristiana, y del obispo BUTLER, teólogo y filósofo moral inglés cuya obra se desarrolla durante la primera mitad del siglo XVIII ${ }^{9}$. Estas clases causaron una enorme impresión sobre el joven RAWLS, despertando en él un inusitado interés por la religión, y más concretamente por las doctrinas teológicas, así como por su relación con la ética. Fruto de ello escribirá A Brief Inquiry into the Meaning of Sin and Faith: An Interpretation Based on the Concept of Commu-

7 Prueba de la falta de interés de MALCOM por la religión es que muchos años después, siendo él presidente de la Asociación Filosófica Norteamericana (1972-1973), RAWLS le menciona el curso y ni siquiera recuerda haberlo impartido.

8 RAWLS utiliza estas palabras, «the quasi-religious topic of buman evil», en una de las entrevistas que durante el verano de 1993 mantuvo con Th. POGGE y que sirvieron de base a este último para elaboración de su libro Jobn Rawls. His Life and Theory of Justice (2007: 11; cfr. NAGEL y COHEN, 2009: 2).

9 Pese a no ser como aquéllos mencionado por RAWLS en su tesina, BUTLER sí aparece citado posteriormente en algunos pasajes de su tesis doctoral de 1950. En el más relevante de ellos (18-20), su doctrina se presenta como una de las varias refutaciones del utilitarismo que sirven de base a su examen de la naturaleza de la teoría ética. En este sentido, es curioso cómo muchos años después, a comienzos de los ochenta, RAWLS incorpora al obispo inglés a las clases que imparte sobre historia de la filosofía moral al considerar que sus enseñanzas proporcionan una de las bases no utilitaristas más significativas para criticar el pensamiento de HOBBES, recurriendo de nuevo básicamente a las mismas obras, Sermons (1726) y Dissertations II: Of the Nature of Virtue (1736). Las cinco lecciones que RAWLS dedica a J. BUTLER aparecen como uno de los apéndices de sus Lectures on the History of Political Philosophy (2007: 416-457). 
nity, trabajo presentado al Departamento de Filosofía de la Universidad de Princeton en diciembre de ese mismo año, en cuya biblioteca, por cierto, ha permanecido desde entonces, y que le permitiría graduarse summa cum laude un mes después, tras haber completado, a causa de la guerra de forma acelerada y un semestre antes de lo previsto, ese último curso.

\subsection{Sobre el pecado y la fe: exposición de las ideas básicas}

\subsubsection{Pecado}

En su interpretación del pecado RAWLS se separa abiertamente de aquellas tradiciones que, de nuevo, él señala como deudoras de la Grecia clásica, y que sitúan el origen del mal, y por tanto, también el del pecado, en el «mundo sensible». En estas concepciones el «hombre malvado» aparece como aquel que, dominado por las pasiones, es «incapaz de controlar sus apetitos», dejándose arrastrar por el deseo hacia las cosas que se muestran ante sus sentidos. De ahí que, aun trasladada esta visión al ámbito de la teología, se continúe entendiendo que son los deseos, las pasiones y, en definitiva, los apetitos del hombre «la raíz del pecado» (vid. 143, 145).

Los apetitos, mundanos o no ${ }^{10}$, pueden, reconoce él, estar relacionados con el pecado. Pero, aun cuando sólo tomásemos en consideración los que son meramente corporales y aluden a la naturaleza física del hombre, como el hambre o la sed, en la medida en que, según RAWLS, existe en la naturaleza humana algo muy distinto a lo corpóreo y que tiene que ver con la capacidad del hombre para corresponder al amor recibido, pero, al mismo tiempo, y por idéntica razón, también para despreciarlo, y que no es sino el espíritu, en esa medida, puede afirmarse, dice RAWLS, que el elemento verdaderamente causante del pecado, totalmente distinto a los apetitos, y que, éste sí, en sí mismo además, es pecado, es «aquella perversión del espíritu que corrompe las relaciones personales» y que es la que le confiere al pecado el carácter aniquilador que posee y que lo define como tal $(146,148,151-152)$.

Para RAWLS ha de buscarse el origen del pecado, y con él la explicación del mismo, en una «región de la experiencia», así la denomina, que no es la natural (179), sino aquella en la que las acciones por medio de las cuales las personas tratan de relacionarse las unas con las otras no pueden describirse mediante conceptos propios de las relaciones naturales, tales como los de deseo o necesidad, no al menos si les conferimos un sentido, por así decir, «apeticional», sino antes bien a través de términos como los de fraternidad, comunidad, generosidad o amor, o, por el contrario, los de odio, envidia o soberbia. Por tanto, son las relaciones personales las que, según él, proporcionan el escenario en el que el pecado desarrolla su actuación (180).

${ }_{10}$ Ampliando la visión más frecuente de los apetitos, que los identifica con las necesidades e impulsos de naturaleza más puramente física, RAWLS distingue cuatro categorías básicas dentro de los mismos, según sea el tipo de objeto al que se éstos refieran: «concretos», como el hambre o la sed; «racionales», como el anhelo de verdad o de coherencia; «estéticos», como el deseo de disfrutar de la belleza; e incluso «religiosos», como el ambicionar a Dios. No obstante, excluye la legitimidad de los últimos, que implicarían considerar a Dios como un objeto, lo cual sería pecar (vid. 180-183). 
Puesto que es esa misma capacidad para la comunidad que el hombre posee, y que él identifica con el espíritu (148), la que puede de igual forma corromperse sin que nada ajeno a ella misma lo provoque (vid. 191-192, 202), para RAWLS las causas del pecado, identificado con la corrupción y destrucción de la comunidad, también poseen, por así decir, una «naturaleza comunal» (189). De modo que para entender la naturaleza del pecado debe tomarse como referencia la del propio hombre, un ser creado para vivir en comunidad y hacerlo por y para ella, y en el que los dones que lo adornan deben considerarse instrumentos a tal efecto (192-3). En este sentido, dado que la capacidad del hombre, que define su naturaleza, para formar parte de la comunidad, para la cual ha sido creado por Dios a su imagen y semejanza (204), es precisamente consecuencia de esa semejanza con Dios, en sí mismo, como explica la «Doctrina de la [Santísima] Trinidad», comunidad $(113,121,193)$, parece claro, arguye RAWLS, por qué debe interpretarse como pecado cuanto supone, de algún modo, la negación del «verdadero fin del hombre» (193), esto es, el desprecio de aquello para lo que ha sido concebido, la comunidad, un desprecio que, a su vez, implica el de Dios, su Creador (203-204).

Todas las acciones del pecador apuntan así en idéntica dirección, entrañan despreciar la comunidad y abusar de ella por y para sí mismo (203), pues para el joven RAWLS el pecado tiene que ver en esencia con todo aquello que, de una u otra forma, comporta la «destrucción de la comunidad». Manifestaciones típicas al respecto son negar toda obligación a la que uno pudiera encontrarse sometido o no corresponder en extremo alguno a la generosidad o el amor recibidos, y, en general, podríamos decir, subvertir y corromper la naturaleza de cualesquiera relaciones personales (122). El pecado, como una perversión aparentemente imposible de erradicar, que amenaza las relaciones de las personas, siempre al acecho, y de la que nadie parece estar lo bastante a salvo, está relacionado, por tanto, con todo aquello que destruye cualquier «relación responsable» con los demás y que socava los cimientos de la propia comunidad (193-194).

Pero si el hombre es por naturaleza un ser «comunal», esto es, «una criatura creada en y para la comunidad» (206), y el pecado no hace sino destruir la comunidad, consecuencia inmediata e inevitable del mismo sólo pueden ser la «soledad» y el «aislamiento» espirituales del propio hombre, «desoladora clausura», escribe RAWLS, que lo encierra dentro de sí mismo y lo separa de sus semejantes $(123,206)$.

\subsection{2. $\mathrm{Fe}$}

El joven RAWLS, de forma quizás algo abstracta e incluso imprecisa, concibe la fe como una suerte de «disposición espiritual» propia de aquella personalidad que forma parte de la comunidad, en el seno de la cual no sólo permanece plenamente integrada, sino que encuentra acabada razón de ser. Para RAWLS la fe representa una «relación perfecta» entre personas, de una persona con otra y de éstas con la comunidad, de la que nacen además los lazos que mantienen unida a la propia comunidad, el más importante de ellos el «amor cristiano» (243), configurando, en consecuencia, una relación de naturaleza tanto personal como comunal, una relación que en última instancia lo es con Dios, con el que el hombre se relaciona a través de la fe y no de ninguna otra 
forma. Tener fe supone, por tanto, pertenecer, en realidad, ser devuelto (125), a esa comunidad que sirve de sostén a la personalidad y que es la alfaguara de la que brotan, según RAWLS, todos los «dones espirituales» (123-124).

Bajo el prisma rawlsiano, la fe es la «antítesis» del pecado y, aunque pudiera parecerlo, subrayarlo no es algo banal o superfluo, pues RAWLS construye sobre esta idea su caracterización de la fe. De modo que, en su esquema teológico, frente a un pecado que comporta destruir la comunidad, y con ella la propia personalidad (214), la fe supone reconstruirla y cimentarla; si el pecado aparta al hombre de Dios y lo aleja de la comunidad, es decir, provoca su separación de Dios y del propio hombre (243), es la fe la que lo devuelve a aquélla y le permite estar en comunidad con él; y mientras que el pecado supone aquel quedar encerrado dentro de sí del hombre, su aislamiento y soledad espirituales, la fe significa, por el contrario, un abrirse a los demás, que conoce su cenit en la plenitud de la «vida comunal» (214), así como la propia restitución del hombre en la compañia de sus semejantes (124).

La cuestión que se plantea, por tanto, es la de cómo llega el pecador a convertirse en alguien con fe, de qué modo logra salvarse, o en otros términos, la de cómo regresa el hombre a la comunidad, qué le permite abandonar su propio encierro y abrirse a los demás, y en última instancia, de qué manera esa comunidad que los hombres tienen ante sí consigue incorporarse a la «comunidad de todas las personas», a la cual, en verdad, pertenece, e integrase así en el Reino de Dios (214). Pues, aunque pueda renegar de ello y despreciar de este modo a Dios, el hombre lo es a imagen y semejanza de aquél, quien, pese a sus pecados, continúa reclamándolo, y por eso en algún momento terminará irrumpiendo en su soledad, haciendo pedazos su clausura y devolviéndolo finalmente a la comunidad (208-209).

Para ello habrá Dios de revelarse, pues sólo él, esto es, únicamente el propio Dios, puede revelar su personalidad y dirigirse al hombre, siendo su presencia la que ha de trascender a la soledad de éste para acabar con ella y devolverle a la comunidad (124-125). La «Palabra de Dios», que penetra en el encierro del hombre, explica el joven autor, es una llamada a los que le han dado la espalda a regresar a la comunidad, una llamada que significa haber sido elegido para formar parte de ella y que finalmente implica ser reintegrado a la misma (244). Pues es el restablecimiento de la comunidad, en última instancia, la constitución de la «comunidad celestial», la razón de la elección, y, por tanto, el propósito al que la palabra de Dios se dirige (245-247). La palabra pretende restablecer la comunidad reuniendo y reconciliando al hombre con Dios y con los demás hombres. Y por eso es un «mensaje» que avanza universalmente, pues es una nueva que ha de extenderse a todos, siendo como es una llamada a regresar a la comunidad cuyos destinatarios son todos los hombres (248). Pero esa restitución de la persona a la comunidad, además de ser consecuencia de la «elección de Dios», y considerarse también un «regalo de su amor», sobre todo supone, con ella la identifica expresamente RAWLS, su conversión (125), pues, para RAWLS, esa «profunda experiencia» de verse expuesto a la palabra de Dios, a la que los teólogos han denominado conversión, algo del todo extraordinario que a veces le ocurre al pecador, y en la que se percibe el contraste entre todo lo que Dios representa y aquello a lo que el pecado condena al hombre, es la que devuelve a la comunidad a la persona que la sufre y la atraviesa (vid. 232-239). 
Sin embargo, y contrariamente a lo que de entrada pudiera pensarse, según RAWLS, recibir la palabra de Dios, que deja al descubierto los pecados del hombre, hasta tal punto que, ante su infinita bondad, amor y misericordia, será él quien acabe condenándose a sí mismo (239), no es, por tanto, una recompensa, sino, precisamente por eso, una condena, porque Dios se dirige al hombre para destruir sus pecados y no para recompensar sus méritos, de modo que la suya no es una llamada para elogiarle, sino, en realidad, para permitir que se arrepienta (241-242). Pero la palabra de Dios, explica el joven RAWLS, expresa también su perdón. De modo que, recibida aquélla, el «perdón de Dios» le devuelve de nuevo a la comunidad. Ahora la persona que sabe de Dios camina con fe y gratitud, su ser otra vez abierto a Dios y a los demás. Destruido el anterior ser pecaminoso, comienza entonces una «nueva vida» para un espíritu recuperado. Porque la palabra de Dios, subraya RAWLS, no sólo significa aniquilación, del pecado y de cuanto éste implica, sino sobre todo restitución, la del espíritu que ha recibido la llamada de Dios y conocido su perdón, y que, aunque antes caído, regresa, ahora ya erguido, a la comunidad lleno de fe (242-243).

Es la conversión, pues, la que permite restablecer y reconstruir la comunidad. Tras esta experiencia, resuelve RAWLS, la persona que ha sido devuelta al regazo divino se relaciona correctamente con los demás. Ahora ese dar propio de Dios se ha transmitido a su comportamiento hacia otros y su conducta, tratando de actuar conforme a la «gracia» de Dios, sigue su ejemplo de amor y misericordia, que es el que le guía en su «vida comunal». Haber sido expuesto a la palabra de Dios, haberla conocido, posibilita la reconstrucción de la comunidad con otros, a cuyo fin trata el hombre de obrar según el modelo divino. Y así, del mismo modo en que Dios le llamó a él, llama él a otros a la comunidad (248-249). La «actitud fundamental» de los que integran la comunidad es, por consiguiente, ese abrirse a los demás que RAWLS identifica con la fe, una fe que en el seno de la comunidad se traduce en caridad, en bondad, en sacrificio o en amor, todos ellos fuertes lazos que mantienen unida la «comunidad cristiana» bajo el Reino de Dios (250-251), de los cuales, como ya se señaló, el más importante sería el amor, el «amor cristiano» (vid. 250-252). Porque es cierto, reconoce RAWLS, que quienes tienen fe han sido elegidos para volver a Dios, pero en esa vuelta, y con la ayuda de aquél, los elegidos, advierte asimismo, han de recoger por el camino a cuantos permanecen rezagados, deben, por tanto, ayudar a llevar a Dios a todos los hombres (252).

\subsection{Al contrario que Pablo de Tarso}

Todo ese fervor religioso del joven RAWLS, y con él la aceptación de las doctrinas religiosas propias del cristianismo, no tardará demasiado en desaparecer, si bien, como a menudo ocurre, no será producto de la casualidad. En efecto, RAWLS se había incorporado al ejército norteamericano inmediatamente después de su graduación. Su periplo militar le llevará a permanecer destinado en el Pacífico dos años, durante los cuales combatirá en el frente, será herido y también condecorado, formando parte de las fuerzas de ocupación en el Japón. Allí conocería de primera mano el horror de Hiroshima, hecho que sin duda no resulta ajeno al artículo que escribiría medio siglo después: «Fifty Years after Hiroshima» (1995). En él, además de cuestionar el lanzamiento de bombas incendiarias sobre las ciudades japonesas desde la primavera 
de 1945 y el posterior de la bomba atómica el 6 de agosto de ese mismo año, hace lo propio con los bombardeos aliados sobre las ciudades alemanes con la guerra ya en su tramo final.

Pero con el fin de la guerra también llegará a su término la ortodoxia religiosa del joven RAWLS, cuyas creencias cambiarían durante una contienda a la que llegó siendo un ferviente y ortodoxo cristiano episcopaliano y de la que se irá habiendo abandonado por completo tal condición, y con ella toda idea de estudiar teología para convertirse en pastor. De todo ello sólo parece haberse salvado un cierto fideísmo. Las experiencias de la guerra, tanto las vividas en primera persona como aquellas otras más generales y que afectaron a millones de personas en todo el mundo, así como la reflexiones que sobre tales acontecimientos realiza el joven soldado, le llevan, en efecto, en lugar de a reafirmarse, como les ocurriría a otros, en la doctrina cristiana, a cuestionar, también como tantos otros, sus creencias religiosas, renunciando a ellas y abandonando el cristianismo.

Aun a nivel un tanto especulativo, y ajeno a todo afán de cualquier explicación exhaustiva, lo cierto es que en «On My Religion», RAWLS cifra en tres sucesos concretos los posibles orígenes de semejante cambio (2009: 262 y ss.) De los dos primeros formó parte él mismo. El primero de ellos tiene que ver con la instrumentalización política de la doctrina cristiana a manos de un capellán militar. Este pastor, como el propio RAWLS conjetura, probablemente con el propósito de consolar o alentar a la tropa, no tiene el menor empacho en utilizar el sermón de un servicio religioso al que el joven soldado acude para asegurar la intervención de Dios en favor de los soldados norteamericanos en su enfrentamiento con sus enemigos japoneses. Esta tergiversación grosera de la doctrina de la «Divina Providencia» irritó profundamente a RAWLS, tanto como para atreverse a recriminar al clérigo luterano, que era teniente, su comportamiento. El segundo suceso alude a la experiencia de cómo algo tan azaroso como el pertenecer a uno u otro grupo sanguíneo puede decidir la suerte, en este caso la vida, de una persona. Al solicitar el sargento de su compañía dos voluntarios, uno para donar sangre a un soldado gravemente herido, otro para acompañar al coronel en una misión de observación cerca de posiciones enemigas, RAWLS y su compañero y amigo DEACON deciden ofrecerse como tales. Puesto que de los dos resulta ser RaWLS el poseedor del grupo requerido para realizar la transfusión, es él quien se queda en el hospital de campaña, siendo a DEACON, por tanto, al que corresponde acompañar al jefe del regimiento en su tarea. El resultado de ese reparto de quehaceres es que, al poco de partir, DEACON perdería la vida bajo el fuego de mortero japonés, un hecho que conmocionó profundamente a RAWLS. Volvían a manifestarse así los efectos distributivos del azar con los que RAWLS ya estaba familiarizado. No en vano, de niño en dos ocasiones había sobrevivido a enfermedades que habían acabado con la vida de sus hermanos, enfermedades que él mismo les había transmitido, difteria y neumonía, y también bien pronto había comprobado las condiciones paupérrimas en las que muchos de sus vecinos de raza negra vivían, muy diferentes a las de su privilegiada situación como hijo de una familia acomodada. El tercero en realidad es más que un suceso, y alude al paulatino conocimiento que entre los soldados va extendiéndose, a partir, en un primer momento, de las noticias difundidas por los propios servicios de información aliados, sobre la existencia de los campos de exterminio nazis, en definitiva sobre lo que viene ocurriendo con millones de personas en la Europa sometida al Tercer Reich. 
Esos dos incidentes y, muy especialmente, el cada vez mayor conocimiento de lo acontecido en los campos de concentración europeos, amén del gran error que a su juicio fue el para entonces injustificado bombardeo de las ciudades alemanas y japonesas, paradigmáticamente la barbarie atómica, tuvieron, pese a su dispar naturaleza, un enorme impacto sobre él, provocando en el joven RAWLS idéntico resultado: cuestionarse el sentido de la oración y el de la moralidad que la voluntad de Dios parece expresar (ibid., 263). ¿Qué sentido tiene rezar y rogar, se pregunta RAWLS, cuando Dios no atiende las oraciones y plegarias de millones de seres humanos a los que abandona a su suerte? ¿Cómo entender que lo que sucede en el mundo se ajusta a los designios de Dios cuando éste no actúa conforme a las ideas de justicia más elementales que conocemos y en las que tenemos depositada mayor confianza? RAWLS construye así su particular teodicea, pues la existencia del mal, más que proporcionarle argumentos contra la existencia de Dios, le plantea dudas sobre la existencia de una planificación divina de la historia. A juicio de otros eso podría exonerar a Dios de toda responsabilidad a través del recurso a la consabida doctrina del libre albedrío. Pero RAWLS, al haber estado ligado su pensamiento cristiano a la doctrina protestante de la predestinación, no puede recurrir a ella. Por tanto, no es que dude de la existencia de Dios, sino que, en último término, no pudiendo salvar este obstáculo de la manera referida, duda más bien de su necesidad moral. Dios no es moralmente necesario en cuestiones de justicia porque no parece tener que ver mucho con ella si lo que pasa en el mundo se entiende que es cosa suya, y porque, en todo caso, tampoco parece que puedan existir normas de justicia muy distintas a aquellas que consideramos más básicas y seguras.

Su rechazo de la mayoría de las doctrinas cristianas no había hecho más que empezar, pues a lo largo de los meses y años que siguieron a su licencia del ejercito, allá por enero de 1946, su distanciamiento del cristianismo fue cada vez mayor, siempre motivado por objeciones de tipo moral, pues a menudo las ideas sobre la justicia que muchas de aquellas doctrinas expresaban le parecían erróneas, llegándolas a ver a veces como despreciables e incluso aterradoras. Era el caso de doctrinas como las del pecado original, la existencia del cielo y el infierno, la aceptación de la autoridad eclesiástica y su interpretación «verdadera» de la fe como camino hacia la salvación o la doctrina de la predestinación, las cuales, como muchos otros, no podía aceptar: básicamente porque, además de su incongruencia con aquellas ideas básicas de justicia, la imagen que proyectaban de Dios era la de un ser monstruoso ávido de gloria cuyo única ambición era la de afirmar su poder omnímodo, lo que, según él, dificultaba de por sí cualquier intento de tomarlas en serio (vid. ibid., 263-264).

\subsubsection{Sobre ciertas autoimputaciones}

Antes de pasar a ocuparme de otras cuestiones, me gustaría apuntar una que juzgo interesante, y que, en cierto modo, hace justicia al joven RAWLS. Es la siguiente. Resulta curioso que algunas de las doctrinas, ideas o interpretaciones rechazadas por RAWLS tras la secularización de sus creencias, que, como acaba de señalarse, no sólo 
no son ajenas a su distanciamiento del cristianismo, sino que en buena medida son el desencadenante del mismo, y de las que da cuenta en «On My Religion», ya lo habían sido explícita o implícitamente por él mismo cuando todavía era un creyente cristiano ortodoxo (cfr. ADAMS, 2009: 99-101). Me refiero por ejemplo a su desprecio del fariseísmo propio de una religión legalista que pretende retribuir el cumplimiento de los preceptos establecidos por la autoridad religiosa con la salvación (vid. 227 y 229-230) o a su impugnación de una imagen de Dios que lo representa como un ser enfadado e iracundo que no persigue sino castigar a un hombre al que sólo infunde temor (vid. 225-227).

Más sorprendente aún es que algunas de las objeciones que pone al cristianismo pueden considerarse como improcedentes según la versión del mismo por él entonces defendida y que parecería poder evitarlas, por ejemplo, esa última imagen de Dios (RAWLS, 2009: 264) a la que él contraponía la de un Dios próximo y misericordioso, un ser de rostro humano e infinita generosidad cuyo único propósito es conducir a todos los hombres, a los que ama incondicionalmente, a su Reino. De hecho, en A Brief Inquiry RAWLS afirma que en la conversión el hombre se da cuenta de la verdadera naturaleza de Dios, esto es, de cuán enormes son su amor y misericordia, comprendiendo entonces su auténtica bondad (vid. 112, 124 y ss., 232 y ss., 242 y ss.).

Algo parecido puede decirse de aquella otra de que el cristianismo describe un proceso de salvación estrictamente individual, cuyas consecuencias sólo pueden ser nocivas (vid. RAWLS, 2009: 265), interpretación cuyo explícito rechazo constituye uno de los ejes de su trabajo de grado, en el que descarta abiertamente cualquier interpretación escapista o individualista de la misma y a la que contrapone una lectura de la salvación completamente comunal o colectiva, tanto en su proceder como en su propósito. Según ésta, el problema de la salvación es el problema de la comunidad. La interpretación que allí hace del pecado y de la fe no sólo culmina precisamente en su definición de la salvación como la completa restitución de la persona a la comunidad, en el seno de la cual se integraría perfectamente, sino que, al mismo tiempo, supone que se trata de un «proceso comunal», que requiere, por eso mismo, del otro. Cuando el hombre ha sido presa del pecado, explica RAWLS, no puede regresar a la comunidad por sí mismo. Al continuar encerrado dentro de sí, aquél contamina todos sus esfuerzos, condenándolos al fracaso. El hombre no puede, pues, salvarse solo. La salvación supone la existencia de la comunidad y, tras haber sido destruida por el pecado, sólo Dios puede restablecerla revelando su palabra, una palabra, vimos, que sí penetra primero en algunos, pero que, sin embargo, a través de la acción de éstos avanza hacia el resto, para regresarlos también a ellos a la comunidad ( $v i d .126,214-219,231-232$ у 245-247).

De modo que puede decirse que, en cierto sentido y en relación a determinadas cuestiones, el RAWLS secular imputa al cristianismo déficits que en algunos casos el RAWLS religioso ya había tratado en cierto modo de paliar. Me permito, en todo caso, invitar al lector a contrastar por sí mismo algunos de estos extremos. Esto le posibilitará poner en perspectiva, cuando no obligará a hacerlo en cuarentena, algunas de estas tesis posteriores a 1945 recogidas en «On My Religion» al compararlas con las contenidas en su trabajo de 1942 sobre el significado del pecado y de la fe. 


\section{RELEVANCIA Y (DIS)CONTINUIDAD FILOSÓFICA}

Como ya se apunto $A$ Brief Inquiry into the Meaning of Sin and Faith es un trabajo de un marcado, pero no exclusivo, carácter teológico. Dadas sus implicaciones éticas y políticas, su interés es doble: 1) desde el punto de vista teológico, en la medida en que ofrece una versión de la teología protestante entonces dominante en los seminarios y facultades de teología norteamericanas ${ }^{11}$, y 2 ) desde la perspectiva de la filosofía moral y política, por la relación que pueda establecerse entre este escrito de juventud y la obra madura del autor.

\subsection{Desde un punto de vista teológico}

En cuanto ensayo que versa sobre cuestiones trascendentes como el pecado y la fe $A$ Brief Inquiry resultará de interés para aquellos que se sientan atraídos por el estudio de tales asuntos, en especial por las interpretaciones protestantes de los mismos propias de la neortodoxia cristiana de la primera mitad del siglo XX. Para éstos serán imprescindibles los comentarios de R. MERRIHEW ADAMS que acompañan al texto de RAWLS en la edición de Harvard University Press y que, bajo el título «The Theological Ethics of the Young Rawls and Its Background», tratan de ubicarlo teológicamente a partir del análisis de sus contenidos, y también del examen del contexto en el que se gesta el escrito y por el que parece estar influido, en relación a lo cual examina la nómina de autores utilizada por RAWLS en su elaboración. Como puede colegirse ya del nombre dado a su ensayo, para ADAMS lo que más sorprende del trabajo de RAWLS, dado el carácter de su obra posterior, es la naturaleza «inequívocamente» teológica de la teoría ética que esboza (2009: 25), lo que sin restar un ápice a su carácter de ensayo teológico, sin embargo permitiría clasificarlo igualmente como un trabajo de ética teológica (ibid., 31).

En él, pese a lo teológico de la teoría ética expuesta, las bases teológicas están comparativamente menos desarrolladas que las conclusiones de carácter más ético (valga como ejemplo la ausencia, a diferencia de lo que ocurre con los teólogos más significativos del movimiento neortodoxo, de una cristología bien articulada). Aunque se llega a esas conclusiones a partir de una concepción del mundo como una comunidad de personas que se relacionan entre sí (112-113), generalmente se hace a través del examen de las actitudes y motivos de aquéllas, más incluso que del de sus propias acciones, ignorando así criterios más habituales de corrección normativa como los relacionados con el comportamiento de los individuos (ADAMS, 2009: 32). Esto no sólo se compadece perfectamente con una interpretación típicamente protestante según la cual el pecado sería básicamente un estado mental aun antes que el propio comportamiento concreto que pueda seguirle (ibid.), sino con el modo en el que RAWLS particu-

${ }^{11}$ La tesis de RAWLS, no se olvide, estudiante de filosofía, es además un buen ejemplo de la influencia que en aquellos momentos, incluso fuera de los centros que les son propios, la teología protestante tenía en las universidades norteamericanas, particularmente en lugares como Princeton, donde la «cultura protestante» era la preponderante. De hecho, no son pocos los filósofos analíticos de la generación de RAWLS que llegarían a la filosofía a través de la teología (cfr. GREGORY, 2007: 179, 183-184). 
larmente lo concibe, y al que señala esencialmente como una depravación espiritual de la personalidad (cfr. 152, 191).

Con respecto a este primer foco de interés, y con arreglo a lo expuesto por R. M. ADAMS, me gustaría señalar que la tesina de RAWLS es un trabajo confeccionado, en efecto, durante el apogeo de la llamada «neortodoxia cristiana», y que evidencia de manera clara la influencia de este movimiento teológico. Esta corriente del pensamiento religioso, cuyos principales exponentes son K. BARTH y E. BRUNNER ${ }^{12}$, agrupa a teólogos europeos y norteamericanos y fijó durante un buen tiempo la agenda del debate teológico, prácticamente desde los años posteriores a la primera gran guerra y hasta bien entrados los sesenta, cuando a consecuencia de los cambios sociales y culturales se ve relegada a un segundo plano. Como movimiento supone un distanciamiento de la teología liberal protestante en el seno de la cual emerge, y de la que, por tanto, también es deudora, frente a la que trata de oponer, reformulándola, una nueva versión de la vieja y anterior ortodoxia cristiana de siglos anteriores. Aunque reivindica la «fundamentación bíblica», al mismo tiempo, rechaza identificar sin más lo escrito en las Sagradas Escrituras con la palabra del Señor prescindiendo de la figura de la revelación, pues estos autores tratan, renunciando al mero textualismo, que no al rigor en la exégesis, de dar cabida a la interpretación bíblica precisamente como instrumento de esta última: de la revelación divina (ADAMS, 2009: 25-26).

No obstante, en un sentido algo más laxo también es posible hablar de la neortodoxia como un determinado ambiente intelectual que, a partir de ciertas premisas compartidas, va a inspirar la aproximación a la teología de la mayor parte de los teólogos protestantes a lo largo de esas más de cuatro décadas en vez de como una escuela teológica homogénea, en cuyo caso incluiría a pensadores como R. NIEBUHR, P. TILLICH o el teólogo y obispo sueco A. NYGREN. Resulta oportuno matizar esto porque aunque RAWLS escribe su tesis de grado en este contexto teológico, el de la neortodoxia, y en este sentido puede decirse que, sin duda bajo el influjo de este clima, es un escrito neortodoxo, lo que ya no está tan claro es que se trate de una obra de teología neortodoxa (cfr. GREGORY, 2007). Pese a la influencia recibida y evidenciada en el texto, RAWLS a menudo acepta las tesis de esta escuela, digamos, a beneficio de inventario, cuando no las interpreta libremente, permaneciendo ajeno a la mayoría de las polémicas abiertas en el seno de este movimiento. Aunque, siguiendo sus planteamientos, se sirve del pensamiento contenido en la Biblia para abordar las cuestiones a las que trata de dar respuesta, lo hace un poco a su manera, de forma, por así decir, bastante

12 En el prefacio de su tesina, RAWLS señala que BRUNNER es el teólogo de quien más habría aprendido y al que se sentiría más próximo en su concepción de una teología erigida sobre la «naturaleza íntima y personal del universo» (108). Esto nada tiene de extraño, pues la obra de BRUNNER fue para muchos la puerta de entrada a la neortodoxia, en especial en los Estados Unidos, donde en la década de los cuarenta su trabajo era más conocido que el de BARTH, por el contrario más influyente entonces en Europa. A diferencia de lo que ocurre con BRUNNER [Man in Revolt (1937), The Mediator (1934) y The Theology of Crisis (1929)], RAWLS no cita a BARTH en su tesina [The Epistle to the Romans (1921) es considerada por muchos su obra más importante], por lo que no es posible saber si conocía sus escritos. Ambos suizos, reformados y amigos, mantuvieron, sin embargo, una intensa polémica, particularmente a propósito de la denominada «teología natural». Defendida por BRUNNER, asume una cierta ligazón entre razón y revelación, a la que, en cambio, BARTH se opone, por entender que, al conceder ese espacio a la autonomía de la persona con respecto a la acción divina, permite, al mismo tiempo, desligarse de Dios (vid. GREGORY, 2007: 186, cfr. HART, 2001; vid. BRUNNER y BARTH, 1946: libro que recoge los textos de ambos autores que mejor ilustran la polémica). 
desenfadada desde un punto de vista metodológico, revelando su empresa la construcción de una posición religiosa y ética personal, antes que el intento de apuntalar el movimiento en alguna dirección (vid. ADAMS, 2009, 29-31). Al fin y al cabo hablamos de un trabajo muy temprano, y ello pese a las pretensiones que en su mismo prefacio el joven RAWLS le atribuye, en el que de manera quizás un tanto atrevida habla de «revolución» en el seno del pensamiento occidental y de «reconstrucción» de la propia teología (vid. 107-108).

Todavía dentro de este primer foco de interés, merece la pena subrayar también la idea de Dios que RAwLS maneja y que, como ADAMS señala ( $c f r$. 2009, 89 y ss.), aúna aspectos más tradicionales, verbigracia, aquellos que tienen que ver con la Creación (vid. v. gr. 112 y ss., y 120 y ss.) o la doctrina de la Santísima Trinidad (vid. 113, 121 y 193), con otros más neortodoxos referidos por ejemplo al significado comunal de la elección divina o a la revelación de Dios a través de una relación de naturaleza personal y organizada en estructuras esencialmente comunicativas (vid. 124-126 y 244-248). Con respecto a estos últimos, según explica RAWLS, con su elección Dios devuelve a aquellos sobre los que ésta recae, y que conocen así directamente su llamada, a su seno, pues con su palabra reconstruye la relación personal con ellos, permitiéndoles abrirse de nuevo ante él llenos de fe. Pero con su elección también son aquéllos devueltos a sus semejantes, a cuyo propio retorno habrán de contribuir igualmente. De modo que aquellos que son elegidos y devueltos a los brazos de Dios no son, por así decir, rescatados de la comunidad de los hombres para, alejados de los demás, permanecer a salvo allá arriba, sino que, muy al contrario, quedan entonces completa y aún más firmemente entre los hombres, pues su elección no ha de servir sino a la de otros. Los elegidos, afirma RAWLs, lo han sido para difundir, con el sostén y la fuerza de Dios, siempre presente con ellos, su palabra, para transmitirla a todos aquellos que permanecen apartados de la comunidad y para hacer partícipes a los demás de su misericordia a fin de devolverlos a la misma. Por tanto, han sido convocados por él a una tarea: la de restablecer e instaurar la comunidad de Dios, una reconstrucción que no ha hecho más que comenzar con ellos, pues Dios ha de venir él mismo, a través de su palabra, para regresarnos, ahora sí a todos, a la comunidad (125-126, 244-245 y 247).

Recomendable para aquellos que persigan comprender el trabajo de RAWLS en sus coordenadas más teológicas (vid. GREGORY, 2007: 183-197), pero también en relación con las discusiones más recientes que han venido produciéndose en torno a la religión y el liberalismo y a propósito también del resurgimiento de una cierta teología política (vid. ibid., 197-203), será el trabajo de E. GREGORY, publicado incluso antes que el de RAWLS, y cuyo «descubrimiento» de A Brief Inquiry (vid. RAWLS, 2009: 2 y ss.) es en buena medida responsable de que estemos ocupándonos aquí de él.

\subsection{Desde la perspectiva filosófica}

Dado que se trata de una obra producida por uno de los filósofos más importantes de nuestro tiempo, y cuyo trabajo ha girado desde sus inicios en torno a una única y misma cuestión, la justicia política, A Brief Inquiry suscita interés precisamente por la relación que pueda establecerse con su obra madura. Una obra en la que, a medida que 
crece, la religión, referida tanto a las convicciones de las personas como a las doctrinas religiosas, recibe cada vez mayor atención y adquiere mayor protagonismo. Esto en ningún caso, sobra decirlo, debe confundirse con la asunción de premisas religiosas en la elaboración de su propuesta filosófica, sino más bien todo lo contrario, pues en el corazón de la misma, como es conocido, están principios que respaldan la separación de religión y política y que, sin embargo, merece la pena recordar, pretenden poder ser asumidos por esos mismos individuos que profesan distintas doctrinas religiosas. Esa separación, argumenta RAWLS, resulta beneficiosa no sólo para la política, al proteger a los ciudadanos unos de otros y, al mismo tiempo, de sus propias iglesias, sino también para la propia religión al impedir que ninguna de ellas pueda monopolizar el poder político para discriminar o simplemente suprimir al resto de doctrinas, protegiendo, en consecuencia, tanto la «cultura secular» como las diferentes religiones, y fortaleciendo así tanto la democracia como la fe (vid. 1997: 603-604; cfr. 1998, 621).

Dentro de este segundo orden de cosas, señalaré una serie de puntos, tanto de contacto como de fricción, entre esta temprana obra de RAWLS y algunas concepciones posteriores del propio autor. Trato así de fijar algunos de los paralelismos y discontinuidades que cabe establecer entre la cosmovisión del joven RAWLS y su teoría de la justicia.

\subsubsection{Paralelismos}

Como COHEN y NAgEL afirman en la introducción que han elaborado para su publicación, puede decirse que algunas de las «convicciones morales» que la tesina expresa en términos religiosos encuentran continuidad en algunas de las ideas más importantes de la filosofía moral y política rawlsiana ulterior, donde nociones que allí aparecen caracterizadas como teológicas y morales a un tiempo, quedan posteriormente moral y políticamente interpretadas, esto es, secularizadas (cfr. 2009, 7). Sería ése el caso, por ejemplo, de: a) una concepción de la ética que se cimenta sobre las relaciones entre personas cada una de ellas completamente valiosa e irreemplazable; $b$ ) el rechazo del mérito como base de la salvación; c) la crítica al miedo y al egoísmo como fundamentos adecuados de la sociedad, o d) la relación de dependencia que existe, también entre las propias nociones, de persona y comunidad.

a) Frente a los representantes de una «ética natural», sea ésta platónica, aristotélica, agustiniana o tomista, que ignora por completo las bases espirituales y personales que conforman, según él, la esencia más profunda del universo (120), y puesto que, a su juicio, la cuestión moral más importante a la que el hombre ha de enfrentarse tiene que ver con el modo en el que éste puede vivir consigo mismo, pero sobre todo con los demás hombres, el joven RAWLS construye una «ética comunal». Para él ninguno de esos autores entiende el «problema comunal», pues tienen una concepción de la ética centrada en relaciones entre personas y objetos que se consideran apropiados, y que aquéllas deben afanarse en alcanzar, sean éstos el bien en sus diferentes formas, la verdad o el mismo Dios, a quien, no se olvide, tanto A. DE HIPONA como T. DE AQUiNo, señalan como «el objeto más deseable» (114-115). En su opinión, la ética, correctamente entendida, debería, por el contrario, centrarse en las relaciones de unas 
personas con otras (113-114), cada una de ellas única, todas diferentes e irreducibles a unidad mayor alguna (111-112), pues si bien la salvación significa finalmente su integración en la comunidad (126), de la que, por cierto, ya entonces explícitamente advierte que no se trata de un «agregado» de personas (111), no conlleva su disolución dentro de ella (126).

Esta concepción temprana de una moralidad que tiene que ver con las relaciones entre personas, y que supone, en este caso, el rechazo de cualquier aproximación no sólo a la ética, sino también a la teología, desde estructuras finalistas organizadas en torno a relaciones «naturales», parecería enlazar con su crítica posterior a las concepciones morales teleológicas, en especial al utilitarismo. RAWLS imputa a este último precisamente no tomar en serio la separación y distinción entre las personas, su pluralidad, a las que, éste sí, toma en su conjunto como un mero agregado de individuos. En su teoría de la justicia RAWLS asume un deontologismo que no sólo rechaza concebir lo justo como aquello que maximiza lo bueno, sino que también impone restricciones de justicia, que justamente tienen que ver con el igual respeto que todas las personas merecen, sobre el bien de los individuos, con respecto al cual lo correcto, como expresión en la estela kantiana de un principio de igual libertad, tiene prioridad (vid. 1971, SS 5,6 y 40).

b) Si en su trabajo de grado RAWLS excluye el mérito como pasaporte a la salvación, en su teoría de la justicia lo rechaza como criterio relevante para la distribución de «bienes sociales primarios». En el primer caso el argumento es de naturaleza teológica: todo cuanto el hombre posee le ha sido dado inmerecidamente por Dios (vid. 238-242, cfr. 229-230 y 170 y ss.); en el segundo su explicación subraya el papel determinante que desempeñan tanto la «lotería natural», que distribuye las capacidades naturales, como el azar social, que en buena medida gobierna las biografías y circunstancias de las personas (vid. 1971, 15 y 103 y ss., y $\$ 48 ;$; fr. 2001, $\$ \$ 20,21$ y 22).

Sorprende, en efecto, la claridad y rotundidad con la que ya en aquel primer ensayo se expresa RAWLS al respecto. Según él, con su conversión el pecador se da cuenta de su completa dependencia de la comunidad, y, en última instancia, de su total dependencia de Dios, de que nada posee que no le haya sido dado, que la crianza y educación recibidas, la amistad de la que ha gozado, la ayuda que le han prestado, y por supuesto, el sostén que la tierra le ha proporcionado, todo ello, explica, le ha sido entregado por «algún otro» y nada, a la postre, al margen de Dios. En última instancia, todo cuanto posee, sus dotes e incluso su modo de obrar, no son más que un regalo de Dios, ante el que no puede más que mostrarse agradecido, pues si puede comportarse de determinada manera o disfrutar de determinadas circunstancias es porque antes otros, empezando por Dios, lo han hecho de cierta forma con respecto a él o han provisto de ciertas cosas para él, de ahí que nadie pueda atribuirse mérito ni siquiera por sus buenas acciones. Es así que no cabe mérito alguno ante Dios no sólo porque carezca de todo sentido ante la generosidad y la misericordia divinas, que el hombre ahora conoce, sino, sobre todo, porque en realidad ninguno es posible sin Él. El hombre entiende que no es por sus méritos, que no posee según lo anterior, que Dios le ama, porque Dios le ama y le da aun cuando no sea merecedor de ello. La misericordia no sería tal de ser esto diferente. Dios, explica RAWLS, no quiere méritos que recompensar, y que sólo a la soberbia, que es el pecado que termina con 
la comunidad, sirven, sino una comunidad eterna unida por la fe y repleta de dicha y gratitud.

Y más sorprende, si cabe, la continuidad que su teoría de la justicia, bien es cierto que bajo otros presupuestos, en otro contexto y con otros propósitos, muestra sobre este punto. Expuesto de forma sumaria y extremadamente simplificada, viene a decir lo siguiente. A menudo se piensa que las personas merecen aquello a lo que su capacidad o posición les permite tener acceso, y no puede ignorarse la plausibilidad natural con que parece presentarse con frecuencia la meritocracia. Sin embargo, nadie merece las capacidades naturales con las que nace o la circunstancias sociales en las que lo hace, y en este sentido incluso la predisposición para esforzarse en conseguir algo, y ser merecedor de ello en el sentido ordinario del término, está condicionada habitualmente por la existencia de un entorno familiar o social que lo propicie. Mas, puesto que, en última instancia, el bienestar de cada persona depende de un producto social resultado de la participación de todos en un mismo esquema, no parece razonable esperar que su distribución se haga depender del lugar que ocupan en la de tales capacidades o circunstancias. Por tanto, han de proponerse términos de colaboración razonables, es decir que todos puedan aceptar con independencia del lugar que ocupan en semejante lotería, y que una vez establecidos permitan distribuir esos beneficios sociales con arreglo a las demandas legítimas que, en función de los principios que definen aquellos términos de colaboración, y no de un mérito aleatorio en sus orígenes, el sistema normativo reconoce como tales. De modo que la influencia del mérito, si se quiere seguir utilizando el término, sobre la distribución de ventajas sociales sólo es aceptable si significa retribuir expectativas generadas por un sistema de cooperación justo en su conjunto y conforme a cuyas normas se actúa y se hace uno acreedor del mismo.

Así pues, dada la dependencia que tanto el joven como el maduro RAWLS entienden que existe del otro, sea de Dios y de los demás hombres, sea sólo de éstos, ni la salvación tiene que ver con el mérito, en un caso, ni el mérito puede por sí sólo y en ausencia de otros parámetros, básicamente los que definen la justicia, «salvar» socialmente a nadie, en otro.

c) Como ya se advirtió, consecuencia de la interpretación que hace del pecado y de la fe, RAWLS rechaza cualquier teoría contractualista de la sociedad (vid. 126-127), lo que permitiría establecer diversos puntos de contacto, pero también de fricción, con su teoría de la justicia a propósito de esta cuestión. En cualquier caso, dentro de los primeros que son los que ahora nos ocupan, quisiera llamar la atención sobre uno que, a su vez, se apoya sobre dos ideas básicas. Por una parte, para el joven RawLS es el miedo a las pretensiones de sometimiento de unos hombres sobre otros, pecado que envenena la mayoría de las sociedades humanas (127), el que a su entender subyace al contractualismo, paradigmáticamente en la teoría política de HOBBES. En la sociedad contractualista los hombres, en efecto, viven temerosos y desconfiados unos de otros, tanto que es justamente sobre ese «miedo mutuo» sobre el que se hace descansar la construcción de la propia sociedad. Ahora bien, siendo el miedo la más egocéntrica de cuantas sensaciones existen, lo cierto, advierte RAWLS, es que ninguna comunidad resulta posible, empero. Pues, de hecho, probablemente nada perturbe más una sociedad que el miedo que pueden tenerse quienes la componen, puesto que cuando los hombres no pueden confiar los unos en los otros, la comunidad está abocada a 
derrumbarse más pronto que tarde. Por tanto, tratar de cimentar la comunidad sobre el miedo, concluye, es algo contraproducente en sí mismo (227-229).

Por otro lado, con arreglo a su explicación, ninguna comunidad puede fundarse sobre egoísmo alguno, según él, una de las formas básicas del pecado (vid. 123, 183 y ss., 193-195). En consecuencia, tampoco cabe que pueda hacerlo sobre la idea de beneficio mutuo, que, en su exégesis de la misma, no es más que una suerte de «egoísmo mutuo». En este sentido, cualquier sociedad que pretenda justificarse tomando como base el «egoísmo mutuo» está, de uno u otro modo, condenada a desaparecer. Y a su juicio, es éste un «defecto básico» del que adolecen todas las teorías contractualistas de la sociedad (188-189). A decir verdad, para RAWLS la sociedad contractualista no puede constituir comunidad alguna, pues no supone más que una especie de estructura orientada a perseguir el beneficio mutuo de quienes pertenecen a ella, un instrumento al servicio de intereses estrictamente individuales. Los hombres sólo recurren a ella con el propósito de obtener beneficios para sí, estando de este modo, se entiende, aunque RAWLS no lo afirme explícitamente aquí, condicionada su continuidad a su conveniencia (227-229).

Pues bien, esta crítica al miedo y al egoísmo como bases inapropiadas de la sociedad encuentra, a mi juicio, una cierta continuidad en su posterior rechazo, dentro ya de su obra madura, de que la unidad social pueda descansar sobre un acuerdo que sea un mero modus vivendi, una idea de reconocida raigambre hobbesiana, a la que imputa precisamente no poder proporcionar una base de justificación adecuada para las instituciones políticas y sociales dada su inestabilidad intrínseca. Semejante pacto, explica RAWLS, descansa básicamente sobre una convergencia coyuntural de intereses meramente individuales, como el miedo a ser perseguido en un escenario distinto o el mayor bienestar que tal situación proporciona, o bien sectarios, como la imposibilidad de imponer una determinada visión del mundo. Esto hace de él, por tanto, un contrato completamente dependiente de circunstancias contingentes, como la distribución del poder entre quienes sustentan el acuerdo, el temor que pueda existir entre unos y otros o los beneficios que se desprendan de dicha forma de coexistencia más o menos pacífica. De modo que la unidad social es solo aparente y la estabilidad completamente frágil y a menudo efímera. Como es bien sabido, RAWLS se sirve de esta idea del modus vivendi para señalar, en buena medida por oposición, los caracteres muy distintos de un «consenso por solapamiento», que se espera pueda, al contrario que aquél, proporcionar una base duradera y estable sobre la que pueda descansar la unidad social en una sociedad democrática (vid. 1985: 410 y ss.; 1987; 1989).

d) En la cosmovisión de RAWLS es su pertenencia a esa comunidad de personas relacionadas con Dios que es el universo, más aún, el haber sido creado para la misma, lo que hace del hombre persona, distinguiéndolo del resto de criaturas de la creación e insertándolo en esa relación con Dios y los demás hombres que resulta inquebrantable y determina el carácter de su personalidad, necesariamente relacionada con aquélla. De acuerdo con esto, es la capacidad para formar parte de la comunidad y participar de ella lo que define estricta e intrínsecamente la propia naturaleza del hombre y en el desarrollo de la cual se convierte propiamente en persona. Sin personalidad, obviamente, no habría comunidad alguna, pues la existencia 
de ésta presupone la de aquélla, pero, no es menos cierto, explica RAWLS, que sin la comunidad la personalidad no sería posible, puesto que los individuos no se hacen personas más que en el seno de la comunidad. De modo que, a su juicio, los conceptos de persona y comunidad, si se quiere individuo y sociedad ${ }^{13}$, en último término, se encuentran en una relación de interdependencia mutua según la cual ninguno de los dos tiene sentido sin el otro (cfr. 112-113, 121, 126-128, 215). Éste es uno de los presupuestos fundamentales sobre los que se apoya el pensamiento de RAWLS en su trabajo de grado. En él aúna aspectos estrictamente teológicos, como los que se refieren al carácter espiritual de la comunidad o al origen divino del hombre, con otros de carácter más bien sociológico, como los que insisten en la idea de que la personalidad se forma en el seno de la sociedad, que es la que le presta el sostén necesario y permite su desarrollo, o aquellos otros que describen cómo sólo tras un largo periodo en el que dependen casi por completo de otras, cabe considerar que las personas puedan contribuir de algún modo a la comunidad y participar del relato comunal.

Aun en un plano estrictamente normativo y dentro de un marco completamente distinto ya en su teoría de la justicia, RAWLS posteriormente retoma esta idea de la dependencia recíproca entre los conceptos de persona (individuo) y comunidad (sociedad) ${ }^{14}$, con arreglo a la cual, sin embargo, la idea más básica sigue siendo la segunda ${ }^{15}$, y también esa otra visión relacionada con el modo en el que los individuos se hacen personas dentro de aquélla. Para un RAWLS ya más maduro el rasgo que define básicamente a las personas, moralmente, es su sentido de la justicia ${ }^{16}$ y éste sólo se adquiere plenamente a lo largo de un recorrido que atraviesa varias etapas, que transcurre en el seno de la sociedad en interacción con otros individuos

13 Vid. infra nota siguiente, en la que se explica la relación entre ambos pares de conceptos.

14 Es bien sabido que en su madurez, a partir de un determinado momento, RAWLS tiene un especial empeño en subrayar que una sociedad democrática, ni siquiera cuando está «bien ordenada», es una comunidad. Como él mismo explica, asumido el pluralismo, la idea de «comunidad política», si por tal se entiende una sociedad política reunida en torno a una doctrina comprehensiva, debe desecharse (1987: 431; vid. 1993: I, $₫ 7$ ). Sin embargo, para poder establecer la comparación que nos ocupa entre ambos extremos de su pensamiento, es necesario por un momento, y en el sentido señalado en el texto, recurrir a una analogía entre los conceptos comunidad y sociedad, conceptos que, por cierto, en su tesis de grado, al igual que ocurre con los de individuo y persona, como ya se habrá advertido, resultan en general intercambiables. En ese escrito, no obstante, RAWLS hace hincapié en la necesidad de considerar a los individuos personas y a la sociedad una comunidad, pues esto sería, según él, lo que permitiría interpretar adecuadamente la relación entre individuo y sociedad (127 y ss.).

15 Tal como RAWLS la entiende, la de sociedad emerge como la «idea central», que en conjunción con la de los «ciudadanos como personas libres e iguales» y la de «sociedad bien ordenada», proporciona la base más adecuada para elaborar, al ser desarrollada junto con aquéllas, la concepción política de la justicia de un régimen democrático. De modo que, aunque RAWLS establece esas tres ideas como básicas, señala la de «sociedad como sistema de cooperación social justo a través del tiempo» como la «más fundamental» entre aquéllas ( $c f r$. 1993: 14 y ss.; 2001: 5). Esto, en ningún caso, debe ocultar el individualismo metodológico sobre el que RAWLS construye su teoría de la justicia, y por tanto, ese carácter básico mencionado que, como enseguida se indica, tiene que ver con una función de organizar y conectar las demás ideas básicas dentro de la teoría de la justicia que se propone, no debe confundirse con la asunción de una visión que conceda prioridad a la sociedad frente al individuo o algún tipo de independencia o personalidad propia de la primera con respecto al segundo.

16 Aunque en este párrafo pongo el énfasis en el sentido de la justicia, que es el que aquí me interesa, y por eso mi primera referencia es «The Sense of Justice», RAWLS suma a esa capacidad la de «tener, revisar y perseguir racionalmente una concepción del bien», que junto a la anterior caracteriza, según él, a las «personas morales» (vid. v. gr. 1980: 312, escrito donde se explica con detalle ese concepto de persona). 
(padres, socios, etc.), y que culmina con la transformación de aquéllas en partícipes plenos de la misma. Esto es, el sentido de la justicia se adquiere socialmente. Y, por tanto, puede decirse que siendo éste el rasgo más importante de la persona es, al mismo tiempo, un atributo que es posibilitado por la propia sociedad ( $c f r$. 1963, 1971, cap. VIII).

Ése sería un primer punto de contacto en torno a esta cuestión. El segundo al que quiero referirme aquí es el siguiente. Abundando en una línea anterior, pero que explícita en su constructivismo de comienzos de los ochenta, RAWLS hace pivotar los principios de justicia básicamente sobre dos concepciones, la de persona moral, en adelante una concepción política de la misma, y la de sociedad como sistema de cooperación social, posteriormente la «idea fundamental» dentro de la cual se organizan y conectan las demás ideas básicas. Y también aquí establece una relación inequívoca y explícita entre ambas concepciones. Hasta tal punto que los atributos de las personas y los elementos de la cooperación social comparten título, «razonable» (sentido de la justicia, términos de cooperación justos) y «racional» (concepción del bien, ventajas para cada individuo). De modo que RAWLS les atribuye a los individuos las capacidades morales que se corresponden con los elementos de la cooperación social y considera ambas concepciones, las de persona y sociedad, como las básicas dentro de la concepción política de la justicia, si bien primero se centra en la de persona, y posteriormente atribuye a la de sociedad como sistema de cooperación ese carácter central ya referido, y que por otro lado, quizás sin advertirlo tan claramente, le venía confiriendo desde el principio (vid. 1982, $\$ 3 ;$ cfr. 1980; 1993, I, $\mathbb{\$} 2: 3,3$ y 5).

\subsubsection{Discontinuidades}

En el apartado anterior acabo de señalar una serie de puntos de contacto entre el escrito de juventud y su obra posterior que permiten hablar de la existencia de determinados paralelismos entre la cosmovisión del joven RAWLS y su teoría de la justicia ulterior. Pero, obviamente, y siguiendo con este segundo negociado referido a la relación de A Brief Inquiry con la obra madura de RAWLS, como ya indiqué, también existen puntos de fricción, tantos como los que implica: a) pasar de una doctrina religiosa que confiere a la política un papel secundario e instrumental a una concepción de la justicia específica e inmediatamente política y que adjudica a esta virtud un carácter completamente prioritario en relación a la estructura institucional básica; $b$ ) apartarse de una idea radicalmente negativa y confesional sobre los orígenes del conflicto social al asumir la normalidad del mismo y la legitimidad de sus causas; $c$ ) abandonar una cosmovisión concreta para buscar el consenso político entre quienes mantienen concepciones del mundo diferentes, $\mathrm{y} d$ ) pasar de afirmar una «ética cristiana» a asumir la separación entre ética y religión. En pocas palabras, RAWLS pasa de concebir como problema más importante uno de carácter metafísico a dar por supuesto que la «cuestión fundamental» es de naturaleza política, y así de una concepción teológica de la comunidad a una concepción política de la sociedad. A continuación me detengo con más detalle en estas discontinuidades, tratando de tejer un argumento que pretende, a través de los puntos sobre los que se enlaza, realzar el contraste entre las ideas expuestas, y, por tanto, entre el ideario cristiano del joven RAWLS y su pensamiento filosófico posterior. 
a) La doctrina religiosa que expone en su trabajo de grado atribuye a la política, y casi de rondón, como misión más importante la de coadyuvar a combatir el pecado a fin de hacer posible la «comunidad espiritual» (203). Para el joven RAWLS la posibilidad de reconciliar persona y comunidad no ofrece dudas (vid. 112-113, 121 y 127), y, por tanto, el verdadero problema, como también señala en relación a la cuestión ética, es el de cómo son posibles ambas, personalidad y comunidad, ante un pecado tan generalizado como el que existe en el mundo. De suerte que la cuestión más importante a la que debe hacer frente la política es la de concebir o alumbrar «algún esquema de organización social» que pueda «enjaezar» el pecado, permitiendo así la realización de la comunidad y la personalidad en los términos de la relación entre ellas expuesta, esto es, de «correlato natural» entre ambas (vid. 127-128).

Pero con la conformación de su teoría madura, RAwLS pasa de una doctrina como ésa, que presupone una relación de supeditación de la política a la teología, a una concepción política de la justicia concebida específicamente para ser aplicada a un objeto muy concreto, el «sistema de cooperación social» que conforman las instituciones políticas, sociales y económicas de una democracia constitucional moderna (1985, 389; 1987, 423). A partir, pues, de una idea de sociedad como empresa compartida, trata de determinar los principios conforme a los cuales esa estructura normativa e institucional básica debe asignar «bienes sociales primarios». RAWLS asume de este modo que es la justicia con la que se realiza semejante distribución, y no la eficacia en la erradicación del pecado, el valor más importante al que debe responder la configuración de las instituciones sociales (vid. 1971, $\mathbb{\$} 1$ y 2,62 y ss., y $\mathbb{1 5}$; cfr. 1978).

b) Con arreglo a su «reconstrucción de la teología» los conflictos que surgen en la sociedad vienen provocados por los distintos pecados, cuyo común propósito, empero, es la destrucción de la propia comunidad (128). Naturalmente esto no es obstáculo para entender que la que él concibe como «comunidad en sentido pleno» se sitúa más allá de la justicia. En la «comunidad celestial» (219), a la que se refiere de ese modo, y en la que finalmente habrá de integrarse, según RAWLS, la humana (214), no existen las disputas que explican la necesidad de esta virtud ${ }^{17}$. Aunque esto último no es exclusivo de las doctrinas religiosas, véase por ejemplo el marxismo, cuya descripción de la sociedad comunista excluye la existencia misma de las circunstancias que obligan a recurrir a la justicia.

Posteriormente RAWLS abandona esa idea radicalmente negativa y confesional sobre los orígenes del conflicto al asumir que los que afloran en la sociedad forman parte de una situación natural dentro de una vida en común, dando por sentado que son producto de las demandas que las personas realizan sobre los beneficios o ventajas sociales: de suyo; todas desean la mayor cantidad posible y los disponibles en condiciones normales nunca son suficientes. Estas demandas enfrentadas traen su causa de los planes o concepciones de la vida que cada una de ellas tiene y que les llevan a tener sus propios fines y propósitos, y, al mismo tiempo, ponen de manifiesto la existencia de

17 Como el propio Rawls ha explicado, en una comunidad de santos, si es que ésta pudiera existir, difícilmente podrían suscitarse las disputas relacionadas con la justicia. La justicia es una virtud que presupone la existencia de intereses enfrentados y de demandas en conflicto, tiene que ver con la existencia de sujetos que insisten en hacer valer sus pretensiones unos frente a otros y que se consideran a sí mismos representantes de intereses que han de ser tenidos en cuenta ( $c f r .1958: 56$ y ss.). 
una diversidad de creencias religiosas y morales, así como de un buen número de doctrinas políticas y sociales. Ese trasfondo social, al que RAWLS se refiere como las «circunstancias de la justicia», explica la necesidad de principios que definan la distribución correcta de tales beneficios, además del de los debes sociales. Esto no sólo implica el reconocimiento de la normalidad del conflicto, con el del pluralismo característico de las sociedades democráticas, sino, más concretamente, también el de la legitimidad de sus causas, idea esta última que encuentra perfecto desarrollo en eso que posteriormente denominará las «cargas del juicio», que explican cómo el desacuerdo es posible incluso entre personas razonables (vid. 1971: 4 y ss., y $\$ 22$; y 1989: 475-458).

c) El joven RAWLS posee una visión sobre la naturaleza del universo, el sentido de la existencia humana y el camino hacia la vida eterna (vid. v. gr. 112 y ss., 123-126 y 214 y ss.), una concepción integral de la persona y una interpretación de su realización en la vida en comunidad. La suya es toda una cosmovisión que incorpora como parte de la misma un determinado modo de ser, de sentir y de comportarse del hombre como forma de salvación, que, en último término, evidencia la ausencia de una concepción ética de lo político independiente de doctrinas metafísicas y de todo cuanto aquélla comporta.

Andado el tiempo, y abandonada mucho antes esa doctrina concreta, desde una reinterpretación progresiva del papel de la filosofía política en una sociedad democrática que reafirma la naturaleza práctica de su empresa (vid. 1980: 306, 330 y 358; 1985: 391, 394; 1987: 421 y 447 y ss.; 1989: 486 y ss.), y, en este sentido, a través de una paulatina «autocomprensión» de los presupuestos y de la función de su propia teoría (cfr. RODILLA, 2006: 82 y ss.), RAWLS tratará de concebir cómo deben y pueden establecerse e interpretarse las bases de un consenso político democrático. Pero no de uno cualquiera, sino de un consenso destinado a servir como fundamento de un régimen constitucional que resulte aceptable para ciudadanos que justamente no comparten las mismas doctrinas religiosas, ni tampoco filosóficas o morales, pasando así del monismo que nace de la religión al pluralismo que requiere de la política.

d) Como ferviente creyente RAWLS afirma que la ética, correctamente entendida, debería centrarse, en efecto, en las relaciones de unas personas con otras, pero también en la de éstas, en último término, con Dios, conformando de este modo una «ética cristiana». No cabe separación alguna entre la religión y la ética ya que las cuestiones de las que ambas han de ocuparse, explica él, en realidad tienen que ver con «el mismo nexo de relaciones, [...] aquellas [...] que implican a todas las personas que existen en el universo, sea en el cielo [...] o en la tierra» (113-114, vid. 116 y 205-206). Y por tanto, así como porque el hombre es un ser «personal y comunal por naturaleza», debe la ética centrarse en la comunidad y en la personalidad, del mismo modo, porque la comunidad a la que el hombre, en última instancia, pertenece es la «comunidad celestial», no puede aquélla separarse de la teología (128).

Por el contrario, en sus escritos posteriores, RAWLS asume todo lo explícitamente posible la separación entre ética (política) y religión (metafísica) como presupuesto básico de su filosofía política, al interpretar su teoría como un modo de «liberalismo político» (cfr. 1985: 408; 1987: 446; vid. 1993: xxxi) y su concepción de la justicia como una concepción «política y no metafísica» (cfr. 1985: 389). De esta manera trata de construir una concepción capaz sobre todo de mantenerse independiente de doctrinas 
filosóficas, religiosas y morales «comprehensivas», es decir, de aquellas doctrinas que, como la del joven RAWLS, incluyen concepciones sobre qué es lo humanamente valioso o ideales de virtud y carácter que pretenden gobernar y moldear la existencia humana en su conjunto (vid. 1985: 408; 1987: 424; 1988: 450; y 1989: 480-481).

En suma, en su trabajo de grado RAWLS asevera que la cuestión que debería tratar de resolver la ética, e incluso, afirma, también la política, es la de cómo es posible la comunidad, sí, pero la de cómo ante el pecado que, inevitablemente quizás, existe en el mundo y que es en sí mismo el verdadero responsable de su destrucción (128). En consecuencia, concibe como cuestión más importante de la filosofía moral y política una cuestión metafísica, con lo que esto implica para aquéllas al reducirlas a meros instrumentos de la teología. En cambio, en su madurez RAWLS se propone abordar una cuestión ética, en este caso pública, recurriendo, en todo caso, sólo a las herramientas propias de una filosofía política, dando por supuesto que la «cuestión fundamental», con respecto a la justicia política, y en esta comparación con respecto a la ética que aquélla representa, en un régimen democrático no es aquella del pecado, sino la posibilidad misma de una sociedad justa, estable y, por tanto, perdurable, cuyos miembros, ciudadanos libres e iguales, permanecen, sin embargo, profundamente divididos por doctrinas religiosas, filosóficas o morales (vid. 1993: 3-4); si se quiere, para realzar el contraste, la de si es posible una comunidad, utilizado este término aquí con todas las prevenciones que el «lector rawlsiano» $\operatorname{conoce}^{18}$, con esos valores de justicia y estabilidad, en vista de la diversidad de doctrinas que existe, y no de eso que algunos llaman pecado.

Sea como fuere, aunque el análisis sistemático y pormenorizado de los diversos paralelismos y discontinuidades que pueden establecerse entre la tesina de RAWLS y su obra posterior, sólo de algunos de los cuales quise ocuparme a modo de ejemplo y sin mayores pretensiones, requeriría de un trabajo más amplio, estoy seguro de que el lector familiarizado con los escritos del filósofo norteamericano no tendrá dificultad para localizar el resto.

\section{ADVERTENCIA PARA NAVEGANTES: CLÁUSULA DEROGATORIA FINAL}

Como señalé al comienzo de estas páginas, la biografía de RAWLS no es esencial para comprender su obra, desde luego no para entender su teoría de la justicia como una forma de liberalismo político, lo que no es óbice, como también indiqué, para asumir que muchas de las experiencias vividas por RAWLS a lo largo de su vida influyeron en el desarrollo de su pensamiento, particularmente en relación a cuestiones como las que en este trabajo he tratado de abordar. Pero una cosa es explicar, como se hizo, qué despierta el interés de una persona, en este caso de un pensador como RAWLS, por un asunto como la religión y, más concretamente, por las doctrinas teológicas del cristianismo, o qué provoca el que termine abandonándolo, y otra bien diferente sería pretender que tales motivaciones puedan, trascendiendo los márgenes de la producción científica que resulta de aquel interés, equipararse en algún sentido a los propios

${ }_{18}$ Cfr. supra nota 12. 
escritos del autor o a las piezas de su obra, o siquiera revelar algo así como un sentimiento latente a la misma.

De modo que he renunciado expresamente desde el principio a recurrir, en uno u otro sentido, a argumentos tales como: sin ser un creyente, a lo largo de su vida RAWLS «mantuvo una mirada esencialmente religiosa» (cfr. ROGERS, 2002), la «motivación espiritual» que convirtió a RAWLS en quien es es la que su misma tesis de grado evidencia (NAGEL y COHEN, 2009: 4), o el que ha informado su vida y sus escritos, cualesquiera que hayan sido sus creencias, es un «temperamento profundamente religioso» (ibid., 5), por poco sentido estrictamente confesional, por así decir, que se pretenda atribuir a tales afirmaciones. Argumentos que, en todo caso, me parecen poco relevantes si lo que se quiere es analizar con seriedad y rigor lo que $A$ Brief Inquiry significa dentro de la obra de RAWLS, e incluso de forma más amplia y a propósito de ésta, lo que la religión supone en el marco de su teoría de la justicia. En mi opinión, las ideas de un filósofo deben ser juzgadas en virtud de sus escritos, que en el caso de RAWLS no albergan ambigüedad o dudas al respecto, pero en mucha menor medida a través de una imputación de motivaciones o actitudes como las señaladas que tienen más que ver con el análisis psicológico que con el propio examen analítico de las proposiciones teóricas que conforman una obra filosófica, y cuya relevancia, en todo caso, me parece completamente secundaria, por no decir del todo residual.

Del mismo modo, tampoco me ha parecido necesario subrayar determinadas posiciones de RAWLS en torno a ciertos temas de carácter especialmente controvertido y que a caballo entre la ética y política son objeto de discusión pública. Aunque recogidos en sus escritos, y por consiguiente, lícito sería ponerlos sobre la mesa, creo que en la mayoría de los casos revelan una posición personal, en algún caso incluso dubitativa, en lo que a la opinión de RAWLS hace, y en nada alteran la naturaleza de los argumentos que su liberalismo político reconoce como adecuados como forma de razonamiento público y a los que RAWLS siempre se remite. Me refiero, baste citarlo, a cuestiones como el aborto (1993: 243 y ss.; 1996, lvs.), la eutanasia (1998: 617-618, cfr. 1997b), o el matrimonio homosexual (1997: 587 y ss., y 596), asuntos algunos de ellos especialmente sensibles, a menudo para las personas con creencias religiosas, que, por otro lado, no reciben hoy la misma consideración desde el catolicismo que desde el protestantismo, y que, por consiguiente, al menos en lo que se refiere a parte de este último, no plantean la misma controversia. Justo es reconocerlo.

En cualquier caso, confío en que algunas de las «continuidades y discontinuidades filosóficas» referidas en la sección anterior, en el contexto global de este trabajo, puedan poner al lector en la pista de algunas de las relaciones y, a partir de éstas, de las valoraciones entre las posibles de establecer y a las que, sin duda, la publicación de esta obra invita. Sin embargo, puesto que no ignoro la tentación, que para el propio RAWLS no era desconocida ( $c f r$. v. gr. 1998), que algunos pueden tener de hacer una relectura religiosa del conjunto de su trabajo, en este caso a propósito de la publicación de su tesis de grado, me permito afirmar que, a mi juicio, cualquier intento de descubrir algo así como una criptoteología agazapada en el trasfondo de su obra madura no se compadecería en absoluto con los presupuestos, propósitos o argumentos, en definitiva, con la propia naturaleza de «la justicia como equidad como forma del liberalismo político». Y es que no cabe confundir el reconocer lo importante que para las personas 
pueden ser sus convicciones, religiosas o no, y, a partir de aquí, todas las cuestiones que la diversidad de doctrinas característica de una sociedad democrática plantea a la filosofía política a propósito de la posibilidad y, por consiguiente, de la naturaleza que debe tener una «base de justificación pública compartida en cuestiones de justicia», no cabe confundir esto, digo, con la asunción de premisas religiosas concretas entre los fundamentos sobre los que se construye una teoría de la justicia. Pero por si lo dicho con anterioridad no fuese suficiente, concluiré este trabajo trayendo unas pocas ideas que, al poner el foco sobre ellas, desarmarán cualquier intento de darle la vuelta a RAWLS y ponerle sotana alguna.

1. La historia de la Iglesia es también la de sus lazos con el Estado y la de su instrumentalización del poder político para garantizar su supremacía y perseguir a quienes disienten de su doctrina. No son palabras mías, sino, amén de un lugar común en el pensamiento occidental, del propio RAWLS (cfr. 2009: 264 y ss.). Esta idea, producto del interés que a la vuelta de la guerra se despierta en el joven RAWLS por todo cuanto rodea a la figura de la Inquisición ${ }^{19}$, pronto le lleva a asumir la libertad religiosa como uno de los «puntos fijos» de su ideario moral y político, y por supuesto, de su propia concepción de la democracia, que evidencia en la consabida separación entre Iglesia y Estado. La libertad de conciencia no sólo pasa explícitamente a formar un presupuesto básico de su teoría bien pronto, sino que RAWLS también entiende que, así como ocurre con su fundamento, cualquier limitación sobre la misma sólo puede explicarse por razones de justicia que apelan a lo que todos pueden aceptar y no a premisas metafísicas (vid. 1963, esp. 86-95; cfr. 1971, \$\$ 33 у 34).

2. Porque si algo en adelante parece tener claro RAWLS, cuyas lecturas sobre la Reforma, lo que la fragmentación de la unidad religiosa que ésta produjo supuso y sus enormes implicaciones políticas y sociales son determinantes al respecto, es que únicamente el recurso a la fuerza a través de los instrumentos que el poder político proporciona puede asegurarle a una doctrina religiosa, filosófica o moral el ser afirmada de forma general y excluyente por todos ${ }^{20}$. Aun sin el empleo de los poderes coercitivos del Estado, cuando una doctrina comprehensiva es socialmente compartida de forma mayoritaria, explica RAWLS, tiende ya a tornarse ciertamente asfixiante para quienes no la profesan, y, por tanto, un «acuerdo público», si es que esto puede denominarse así, sobre una concepción de este tipo como base de justificación pública no parece posible sin la amenaza permanente de violentar los derechos más básicos de quienes no compartan esa moralidad oficial (cfr. 1987: 425).

3. Es así como la reflexión sobre las condiciones sociales e históricas en las que se desarrollan las democracias modernas, entre cuyos orígenes las guerras de religión ocupan precisamente un lugar destacado, y particularmente la interpretación que RAWLS

19 Mucho después RaWLS relacionará los males de la Inquisición con los del Holocausto que tanto le impresionó entonces, al entender no sólo que sin el antisemitismo que creció al abrigo del cristianismo durante siglos anteriores es más que probable que aquél no hubiese ocurrido, sino incluso que la propia visión que Hitler tenía del mundo era perversamente religiosa (cfr. 1999b: 20 y 22).

20 Como el propio RAWLS recoge en su trabajo, es precisamente a través de los poderes coercitivos del Estado como, al menos desde Constantino, el cristianismo trató de imponer su doctrina, castigando la herejía, a la que pretendió eliminar a través de la persecución y la guerra, en un «celo persecutorio» que ha sido justamente su «gran maldición» y que no es exclusivo del catolicismo, sino también característico de reformistas como Lutero o Calvino, tan «dogmáticos e intolerantes» en este sentido como entonces la Iglesia Romana (1999b: 21; 1993: xxv). 
hace sobre las consecuencias que para la filosofía moral y política tienen estas circunstancias, es la que lleva a RAWLS a asumir lo que él mismo denomina el «hecho del pluralismo» (cfr. 1982: 17 y ss.; 1982b: 360 y ss.; 1985: 412; y vid. 1987: 425, donde se define como tal). RAWLS toma conciencia de que el proceso de racionalización característico de la Modernidad ha generado una diversidad de doctrinas religiosas, filosóficas y morales que, efectivamente, plantea a la filosofía política la cuestión de cómo es posible, dado que ninguna es compartida por todos, construir un consenso fundamental entre personas que sustentan visiones del mundo no sólo diferentes, sino a menudo antagónicas. Como ya se advirtió, RAWLS intenta hacer frente a ese interrogante interpretando su teoría como un modo de «liberalismo político» (cfr. 1985: 408; 1987, 446; vid. 1993, xxxi) y su concepción de la justicia como una concepción «política y no metafísica» (cfr. 1985: 389).

4. Dentro de su teoría RAWLS interpreta este fenómeno del pluralismo no como una circunstancia desgraciada, sino, en buena medida, como la consecuencia inevitable del ejercicio de la razón práctica en el marco de instituciones libres, suponiendo no sólo que se trata de una característica permanente de la «cultura pública» democrática, sino también que se trata de un «pluralismo razonable» (vid. 1993: I, $\$ 6.2$, e índice analítico), es decir, integrado por «doctrinas comprehensivas razonables» (vid. 1993: II, $\mathbb{S 3}$ ), que aceptan el régimen democrático y su idea de legitimidad política. Pero RAWLS no sólo asume, de forma general y en el plano normativo, que algunas de estas doctrinas razonables son religiosas (1993: xx), sino que también constata que, de hecho, los católicos, de acuerdo con el Concilio Vaticano $\mathrm{II}^{21}$, afirman las instituciones políticas de un régimen constitucional, y lo mismo ocurre, según él, con la mayoría de cristianos protestantes, judíos e incluso musulmanes (1998: 621).

5. En vista de las enormes diferencias que, como mínimo a partir la Reforma protestante, semejante diversidad de doctrinas genera, del mismo modo que no parece posible ponerse de acuerdo sobre cuestiones doctrinales, religiosas o morales, tampoco parece razonable pensar que alguna de estas doctrinas pueda proporcionar una base común, y a la vez viable, para articular, como «base de justificación pública compartida en cuestiones de justicia», la concepción política de la justicia de una sociedad democrática. Esto no implica, en absoluto, negar las doctrinas religiosas, filosóficas o morales, ni tampoco rechazar las explicaciones filosóficas sobre la naturaleza de la verdad o el estatuto epistemológico de los valores, sino, simplemente, evitar discutir sobre doctrinas comprehensivas y controversias filosóficas, siguiéndose así un «método de evitación» que al «aplicar el principio de tolerancia a la filosofía misma» trata únicamente de formular una concepción política de la justicia $(1985: 388,395$; 1987 : 434-435).

6. Por tanto, como consecuencia del propio pluralismo, y como, en efecto, ponen de manifiesto los demás «hechos generales» de la sociología política y la psicología humana, entre ellos el antes referido a propósito de la coacción (cfr. 1987: 425; vid. 1989: 474-475, 478; y 1993: 36-38, 58), queda descartada la posibilidad de elaborar una concepción de la justicia capaz de servir como «foco» para un consenso polí-

${ }_{21}$ Según Rawls, no es hasta dicho Concilio cuando, con la Declaración Dignitatis Humanae (1965), la Iglesia Católica se separa indubitadamente de aquel afán persecutorio ya mencionado al comprometerse con el principio de libertad religiosa tal y como se entiende en una sociedad democrática (1999b: 21 y ss.; sobre este cambio doctrinal, cfr. GARRÁN, 2000: 440-449). 
tico básico entre personas que sustentan cosmovisiones diferentes ( $v i d .1985$, 390; vid. más esp. 1987 y 1989) tomando como base cualquiera de las doctrinas comprehensivas controvertidas o en litigio.

Como muestran sus escritos, más allá de cuáles fueran sus convicciones, religiosas o no, RAWLS siempre tuvo fe: fe en que una sociedad justa es realmente posible, y por eso, en su madurez y reinventando a KANT, confió a la filosofía política la defensa de esa posibilidad. Sea o no un sueño, como bien dijo N. MACCORMICK, «la propuesta merece ser considerada con seriedad» (1982: 90).

\section{BIBLIOGRAFÍA}

ADAms, R. M., 2009: «The Theological Ethics of the Young Rawls and Its Background», en Rawls, 24-101.

APEL, K.-O., 1973: «El a priori de la comunidad de comunicación y los fundamentos de la ética», en su obra La transformación de la filosofía II, trad. cast. de CORTINA, CHAMORRO y ConIL, Madrid, Taurus, 1985, 341-413.

BERLIN, I., 1953: El erizo y la zorra. Tolstoi y su visión de la historia, trad. cast. de C. AgUILAR, Barcelona, Península, 2009.

BRUnNer, E., y BARTH, K., 1946: Natural Theology: Comprising «Nature and Grace» by Professor Dr. Emil Brunner and the Reply «No!» by Dr. Karl Barth, english traslation by Peter Fraenkel, Eugene (Oregon), Wipf \& Stock Publishers, 2002.

COHEN, J., y NAGEL, Th., 2009: «Introduction», en Rawls, 1-23.

FreEman, S., 2003: «Introduction. John Rawls-An Overview», en S. FreEman (ed.), The Cambridge Companion to RAWLS, Cambridge, Cambridge University Press, 1-61.

- 2007: Rawls, London, Routledge.

- 2007b: «Editor's Foreword», en Rawls, ix-xvi.

GARRÁN, J. M. ${ }^{a}$, 2000: «Algunas reflexiones en torno al magisterio de la Iglesia Católica sobre los derechos humanos a partir del Concilio Vaticano II», en Anuario de Filosofía del Derecho, n. e., t. XVII, 439-462.

GRAHAM, P., 2007: Rawls, Oxford, Oneworld.

Gregory, E., 2007: «Before the Original Position: The Neo-Ortodox Theology of the Young John Rawls», Journal of Religious Ethics, núm. 35, 179-206.

HABERMAS, J., 1983: Conciencia moral y acción comunicativa, trad. cast. de GARCía CotARELO, Barcelona, Península, 1996.

- 1991: Aclaraciones a la ética del discurso, trad. cast. de J. MARdomingo, Madrid, Trotta, 2000.

HART, J. W., 2001: Karl Barth Vs. Emil Brunner: The Formation and Dissolution of a Theological Alliance, 1916-1936 (Issues in Systematic Theology, vol. 6), New York, Peter Lang.

Kukathas, Ch., 2003: «General Introduction», en Ch. KuKathas (ed.), John Rawls. Critical Assessments of Leading Political Philosophers, vol. I, Foundations and Method, London, Routledge, 1-21.

MAcCormick, N., 1982: Derecho legal y socialdemocracia, trad. de GonZálEZ SOLER, Madrid, Tecnos, 1990.

Nozick, R., 1974: Anarchy, State and Utopia, Oxford, Basil Blackwell.

Pogge, Th., 2007: John Rawls. His Life and Theory of Justice, Oxford, Oxford University Press. 
RAWLS, J., 1958: «Justice as Fairness», citado por RAWLS, 1999, 47-72.

- 1963: «The Sense of Justice», citado por RAWLS, 1999, 96-116.

- 1963b: «Constitutional Liberty and the Concept of Justice», citado por RAwLS, 1999, 77-95.

- 1971: A Theory of Justice, Cambridge, Mass., Harvard University Press.

- 1978: «The Basic Structure as Subject», en A. I. Goldman y J. KIm (eds.), Values and Morals, Boston, Reidel, 47-71.

- 1980: «Kantian Constructivism in Moral Theory», citado por RAWLS, 1999, 303-358.

- 1982: «The Basic Liberties and Their Priority», en S. MacMurRIN (ed.), Liberty, Equality and Law. Selected Tanner Lectures on Moral Philosophy, Salt Lake City, Utah University Press, 1-87.

— 1982b: «Social Unity and Primary Goods», citado por RawLS, 1999, 359-387.

- 1985: «Justice as Fairness: Political Not Metaphysical», citado por RAWLS, 1999, 388-414.

- 1987: «The Idea of an Overlapping Consensus», citado por RAWLS, 1999, 421-448.

— 1988: «The Priority of Right and Ideas of the Good», citado por RawLS, 1999, 449-472.

- 1989: «The Domain of the Political and Overlapping Consensus», citado por RawLS, 1999, 473-496.

- 1993: Political Liberalism, New York, Columbia University Press.

- 1995: «Fifty Years after Hiroshima», citado por RAWLS, 1999, 565-572.

- 1996: «Introduction to the Paperback Edition», en la reed. de Political Liberalism, New York, Columbia University Press, xxxvii-lxii.

- 1997: «The Idea of Public Reason Revisited», citado por RAWLS, 1999, 573-615.

- 1997b: «Assisted Suicide: The Philosophers' Brief», cosigned by R. DwOrkin, Th. Nagel, R. Nozick, T. M. Scanlon y J. Jarvis Thomson, New York Review of Books, vol. 44, núm. 5, 27 de marzo.

- 1998: «Commonweal Interview with John Rawls», citado por RAWLS, 1999, 616-622.

- 1999: Collected Papers, en S. Freeman (ed.), Cambridge, Mass., Harvard University Press.

- 1999b: The Law of Peoples, Cambridge, Mass., Harvard University Press.

- 2000: Lectures on the History of Moral Philosophy, en B. Herman (ed.), Cambridge, Mass., Harvard University Press.

- 2001: Justice as Fairness. A Restatement, en E. Kelly (ed.), Cambridge, Mass., Harvard University Press.

- 2007: Lectures on the History of Political Philosophy, en S. FreEMAN (ed.), Cambridge, Mass., Harvard University Press.

- 2009: A Brief Inquiry into the Meaning of Sin and Faith. With «On My Religion», en Th. Nagel (ed.), Cambridge, Mass., Harvard University Press.

Rodilla, M. A., 2006: Leyendo a Rawls, Salamanca, Ediciones Universidad de Salamanca.

Rogers, B., 2002: «John Rawls: Obituary», The Guardian, 27 de noviembre. 